\title{
A Review of the Ecomorphology of Pinnotherine Pea Crabs (Brachyura: Pinnotheridae), with an Updated List of Symbiont-Host Associations
}

\author{
Werner de Gier ${ }^{1,2, *(1)}$ and Carola Becker ${ }^{3}$ \\ 1 Taxonomy and Systematics Group, Naturalis Biodiversity Center, P.O. Box 9517, 2300 RA Leiden, The Netherlands \\ 2 Groningen Institute for Evolutionary Life Sciences, University of Groningen, P.O. Box 11103, \\ 9700 CC Groningen, The Netherlands \\ 3 Vergleichende Zoologie, Institut für Biologie, Humboldt-Universität zu Berlin, Philippstraße 13, Haus 2, \\ 10115 Berlin, Germany; Carolabecker.germany@gmail.com \\ * Correspondence: Werner.degier@naturalis.nl; Tel.: +31-7-1751-9600
}

Received: 14 October 2020; Accepted: 10 November 2020; Published: 16 November 2020

\begin{abstract}
Almost all pea crab species in the subfamily Pinnotherinae (Decapoda: Brachyura: Pinnotheridae) are considered obligatory endo- or ectosymbionts, living in a mutualistic or parasitic relationship with a wide variety of invertebrate hosts, including bivalves, gastropods, echinoids, holothurians, and ascidians. While the subfamily is regarded as one of the most morphologically adapted groups of symbiotic crabs, the functionality of these adaptations in relation to their lifestyles has not been reviewed before. Available information on the ecomorphological adaptations of various pinnotherine crab species and their functionality was compiled in order to clarify their ecological diversity. These include the size, shape, and ornamentations of the carapace, the frontal appendages and mouthparts, the cheliped morphology, the ambulatory legs, and the reproductive anatomy and larval characters. The phylogenetic relevance of the adaptations is also reviewed and suggestions for future studies are made. Based on an updated list of all known pinnotherine symbiont-host associations and the available phylogenetic reconstructions, it is concluded that, due to convergent evolution, unrelated species with a similar host interaction might display the same morphological adaptations.
\end{abstract}

Keywords: Decapoda; micro-computed tomography; morphology; parasitism; Pinnotherinae; symbiosis; symbiotic fauna

\section{An Introduction to Pea Crabs}

Symbiotic lifestyles, whether they are considered parasitic, commensal, or mutualistic, can be found in species of almost all major crustacean taxa. Only the remipedes (Remipedia) and horseshoe shrimps (Cephalocarida) form an exception, including no apparent taxa living in or on host organisms [1]. The true crabs (Decapoda: Brachyura) encompass 14 families with symbiotic species [2]. One of these families, the Pinnotheridae or 'pea crabs', currently holds around 320 recognized species [3,4], which can almost all be classified as obligatory endo- or ectosymbiotic [1]. The family is currently split into four subfamilies: Pinnotherinae, Pinnixinae, Pinnothereliinae, and Pinnixulalinae [5]. Members of Pinnotherinae are usually defined as small symbiotic crabs, living commensally or parasitically as endosymbionts between the branchial organs of bivalve, gastropod, and chiton molluscs, inside the pharyngeal basket of ascidians, inside the intestinal or respiratory system of holothurians and echinoids, and ectosymbiotic on the outer surface of various echinoids [6]. In addition, there are exceptional cases of pinnotherines living in brachiopods, on asteroids, and supposedly in decapod burrows and worm tubes $[6,7]$. The complicated multi-staged life history of only a few pinnotherines has been well 
studied [8,9], but remains unknown for most other species. Pinnotherine species which have been identified as free-living are usually described from single specimens and one of the sexes only [6]. Although hard stage males and females are known to leave their (intermediate) host for numerous possible reasons (e.g., copulation during swarming [10]), it is most likely that soft staged individuals collected outside another invertebrate have been dislodged from their hosts [11], or are just venturing shortly outside their hosts [12].

Most members of the subfamilies Pinnixinae, Pinnothereliinae, and Pinnixulalinae [5] can be found as commensal symbionts living inside the holes and tubes of living annelid and sipunculid worms, and inside mud shrimp burrows (Decapoda: Axiidae and Upogebiidae). Although pinnixine, pinnothereliine, and pinnixulaline crabs are known for their co-inhabiting behaviour, around 19 species are still considered to be free-living, whereas seven species are known as obligatory endo- or ectosymbionts. Closer inspection of the free-living species and their habitat is needed in order to confirm whether they are indeed free-living or if their host was simply not found and therefore not collected [13].

While pea crabs are regarded as one of the most specialized groups of symbiotic crabs [14], only few authors succeeded in testing or observing the functionality of their ecomorphological adaptations [15]. In the taxonomic literature, morphological adaptations are commonly only mentioned as part of species descriptions [7,16], while review papers mainly focus on the correlation between the sizes of the host and the symbiont [17], and on the morphology of the anatomical features associated with feeding habits and host choice, which are both thought to drive speciation [15].

Due to their small size and cryptic way of living, the adaptations pinnotherines have evolved in order to live in and on their host are barely understood [18]. This study aims to review the anatomy and hypothesized functional roles of the anatomical structures in pinnotherines, and to illustrate a number of these anatomical features. In this way, we hope to shed more light on the host specificity of the morphological adaptations and whether they have any phylogenetic relevance in the evolution of the whole subfamily. An updated, more extensive list of known symbiont-host relationships of the Pinnotherinae is also given (see Section 3.6), partly based on earlier works $[1,6,11]$.

\section{Studying Pea Crab Morphology}

Traditionally, the morphological features of pea crabs were only illustrated using camera lucida illustrations [19] or photographs [20]. Most of the morphological features we can study using the previous literature is limited to only the third maxillipeds and the dorsal view of the entire female crab, whereas later, the (available) male crabs were also illustrated. More recent taxonomic works also included illustrations of the details of the ambulatory legs (especially the dactyli), chelae, and frontal view of the head region [19]. In more recent morphological papers, scanning electron microscopy (SEM) was used to capture the minute details on the claws [15]. In the present review, we aim not only to include the traditional methods in order to show the morphological features, but also a relatively new way to study both the internal and external morphology of pea crabs, by micro-computed tomography ( $\mu$-CT) scanning.

Three specimens from the Naturalis Biodiversity Center decapod collection (Leiden, the Netherlands; formerly Rijksmuseum van Natuurlijke Historie, RMNH) were selected for their distinct overall morphology, one representing the Pinnixinae (Pinnixa cyllindrica (Say, 1818)), and two representing the variety within the Pinnotherinae (Nepinnotheres pinnotheres (Linnaeus, 1758) for its basic pinnotherine body shape and Xanthasia murigera White, 1846 for its abnormal carapace ornamentations). The three specimens were illustrated using 3D models based on $\mu$-CT: 3D models were made in the Naturalis Biodiversity Center CT-scanning and imaging facilities (Leiden, the Netherlands), using Avizo 9.5.0 volume-rendering software [21] and a Zeiss Xradia 520 Versa 3D X-ray microscope (CT-scanner), of specimens in $70 \%$ ethanol. The following settings were used: Optical magnification of 0.39 , a scanning current of $87.0 \mu \mathrm{A}$, a scanning voltage of $80.0 \mathrm{kV}$, an exposure time ranging from 1.3 to $1.5 \mathrm{~ms}$, and pixel sizes ranging from 23.5 to 27.6 . 
The line drawings in this review were traced from previous literature. SEM pictures of claw morphologies and ornamentations were made at the Senckenberg Research Institute and Natural History Museum (Frankfurt, Germany), from the same samples and using the same methodology as described by Becker and Türkay [15].

To highlight the adaptive evolution of various anatomical features, we have organized the review into the five following sections: carapace shape, size, and ornamentation; frontal appendages and mouthparts; cheliped morphology; ambulatory leg adaptations; and sexual anatomy and larval characters. In addition, we have provided an updated list of all known pinnotherine symbiont-host associations (see Section 3.6).

\section{Adaptations in Pinnotherine Morphology}

\subsection{Carapace Shape, Size, and Ornamentation}

Most pinnotherine crabs are known for their strong sexual dimorphism, in which the females reach larger sizes than the conspecific males. This is most likely linked to their mating systems, in which the trait 'pure-search polygynandry of sedentary females' occurs [22-24]. This is, however, not apparent in all pinnotherine genera, where a different mating strategy is used. Both sexes of the species in the ectosymbiotic Dissodactylus complex (genera Dissodactylus and Clypeasterophilus) share a similar size and shape of the carapace and appendages. These genera are thought to use 'pure-search polygynandry of mobile females' as mating strategies [22,25]. The very subtle sexual dimorphism is thought to be the result of both sexes living on their host, rather than in their host, being able to leave their host and not being restricted to the space in the host's cavities [26]. Similarly, female members of Ostracotheres tridacnae (Rüppell, 1830) and Xanthasia murigera, which inhabit giant clams (Tridacninae), are of the same size and shape as their male counterparts $[27,28]$. It is thought that males reach similar sizes as their female conspecifics due to their spacious Tridacna hosts allowing them to grow larger [12]. Furthermore, male and female members of the holothurian-associated genera Alain and Holotheres share a similar shape and size of the carapace, but males possess relatively stouter chelae and are only slightly (10-20\%) smaller in carapace width and length than females [28,29]. In many pinnotherine species, the morphology of only one sex is known, resulting in limited knowledge on sexual dimorphism in those species [6]. In addition, although sexual dimorphism is most extreme in mollusc-inhabiting pea crabs (e.g., the genera Pinnotheres, Fabia, Arcotheres), it can be found all over the family tree, in association with almost all possible hosts (see Section 3.6).

Size differences between crab species is thought to be linked to specific morphological traits of their hosts, such as microhabitat space [15]. The largest species of pinnotherine crab, Pinnaxodes gigas Green, 1992, has a carapace width of $36 \mathrm{~mm}$ as is reported from the siphon of a large geoduck, the mudburrowing bivalve Panopea sp. [30]. The smallest pea crab species, Nannotheres moorei Manning \& Felder, 1996, can be found in narrow hammer oysters (Malleus candeanus (d'Orbigny, 1853)) barely reaching a carapace width of $1.5 \mathrm{~mm}$ [31]. The smallest Arcotheres species (A. pollus Ahyong \& Ng, 2020) also lives inside a hammer-oyster (M. albus Lamarck, 1819) [32]. Host size does not just explain the interspecific size differences, but also intraspecific variation in the crabs. Cuesta et al. [33] studied the correlations between crabs of both sexes (Pinnotheres bicristatus García Raso \& Cuesta, 2019) and one of their host bivalves, Anomia ephippium Linneaus, 1758. A strong positive correlation was found between the sizes of the hosts and the sizes of the soft-shelled (post-hard) females, with larger hosts harbouring larger post-hard females. The larger size of the females can be explained by their sedentary lifestyle, not having to leave their host ever again. Additionally, being larger is also advantageous for reproductive purposes: larger body sizes can produce larger broods [34]. A similar, but weaker, positive correlation was found between the sizes of male crabs and their hosts; male crabs were always smaller than females in the same host size [33]. It is thought that smaller males looking for mates have access to a larger size range of host individuals [22]. In Pinnotheres pisum, P. taichungae K. Sakai, 2000, 
and probably many more bivalve inhabitants, the size of the host is also positively correlated with the infestation rates within and between host species [35,36].

In addition to the study mentioned above [33], no correlation was found between the size of hard stage females and the size of their newly invaded hosts [37]. This suggests that intruding crabs do not select the biggest host available, but they will be limited in their growth by the size of the specific host. Similar results [15] were found in populations of other bivalve-associated pea crabs from all over the world: Afropinnotheres monodi Manning, 1993 [38], Arcotheres sinensis (Shen, 1932) [39], Austinotheres angelicus (Lockington, 1877) [40], Calyptraeotheres garthi (Fenucci, 1975) [41], Pinnotheres pisum (Linnaeus, 1767) [42], and Pinnotheres tsingtaoensis Shen, 1932 [26]. In addition to these mollusc-inhabiting species, Ahyong [12] found that Austrotheres holothuriensis (Baker, 1907) has a larger maximum size in spacious holothurians than in the mostly smaller ascidian host species. The specialist congeneric A. pregenzeri Ahyong, 2018, however, grows to similar sizes in its comparable ascidian hosts. Similarly, Becker and Türkay [43] found larger Nepinnotheres pinnotheres specimens infesting shells of Pinna nobilis Linneaus, 1758, compared those from ascidian hosts. In general, larger hosts are thought to offer greater food resources than smaller hosts [15].

Based on their reproductive strategies, the shape and rigidness of the carapace can change throughout the multi-staged lifecycle of both female and male pea crabs. Campos [8] suggests two different ontogenetic pathways, based on his own observations and previous literature. In the first strategy, male and female crabs moult into their hard stages prior to host invasion and copulate after invasion of the host. After copulation, the female moults into her more globular post-hard (soft) stages and remains in the host. The hard stage male, characterized by having a well-calcified carapace, is fit for entering bivalve hosts [11] and is suggested to leave the host again [23] and copulate with other host-inhabiting hard stage females to increase its reproductive success [17]. Becker and Türkay [15] confirmed this theory for hard stage males of Pinnotheres pisum, observing the lack of distal segments in their ambulatory legs, likely due to them having been squashed by the closing of their bivalve hosts. During their time between hosts, male crabs of the same species might even use vectors like detached egg-cases of whelk snails (Buccinum) to cover greater distances [44].

This first strategy is found in most pinnotherine genera, but many details remain unknown for almost all species. The second strategy is similar, but differs in a few ways: juvenile crabs infest their (intermediate) hosts in the first post-planktonic stage and moult into a male or female hard stage crab. In this stage, morphological adaptations for swimming develop (e.g., hard carapace and ambulatory leg morphology, discussed later), and both male and female crabs leave their host for copulation in open water (often called swarming behaviour). Afterwards, females infest their terminal host and moult into more globular post-hard stages, while males might still switch between hosts in their terminal hard-stage. This strategy is thought to follow a seasonal pattern $[30,45]$ and is known from members within the genera Austrotheres [12], Calyptraeotheres [9], Fabia [45], and Tumidotheres [8,30]. It is worth noting that swarming behaviour has been observed in Fabia subquadrata Dana, 1851, and Tumidotheres maculatus (Say, 1818) using 'night-light' fishing of a few swarming individuals, as described in Pearce [45]. Another unrelated species, Tritodynamia horvathi Nobili, 1905, which was transferred from the Pinnotheridae to another family [3], is known for its excessive swarming behaviour [46] and might have contributed to the theory that some pinnotherids swarm in a similar way [45].

Interspecific differences in carapace shape and rigidness of post-hard females can be traced back to their specific host range. Endosymbiotic pea crabs known from echinoderms and geoducks (e.g., genera Alain, Buergeres, Holotheres, Holothuriophilus, Pinnaxodes; see Section 3.6) share a firm, round to subangular carapace [30]. Similarly, members of the ectosymbiotic genera Dissodactylus and Clypeasterophilus, all known from the outer surface of flattened sea urchins such as sand dollars, share a flattened, extremely calcified, and somewhat widened carapace, which is thought to be useful for manoeuvering between the spines of sea urchins [47]. This somewhat flattened and wide carapace resembles that of the hard stage males and females of other genera associated with bivalves, like Fabia subquadrata and Zaops ostreum (Say, 1817) [48]. Most crabs of the remaining pinnotherine 
genera known from molluscs and ascidians (with the exception of a few genera discussed below) live securely inside their host and share a globular soft-shelled carapace in the terminal female stages. This feature is usually accompanied by an enlarged pleon for egg development (Figure 1A-C) ([17]; see below). In a few cases, the carapace might be more calcified in specimens infesting certain bivalve groups, like the Arcidae [49]. The reason for this aberrant post-hard stage morphology is not known as for now.

In contrast to the morphological variation within the Pinnotherinae, members within the Pinnixinae, Pinixulalinae, and Pinnothereliinae all share a similar body shape. All representatives of these taxonomic groups have a flattened, wide carapace shape, and usually a third ambulatory leg that is larger in size than the other ones (Figure 1D-F) [18]. This body shape is thought to be the result of the symbiotic lifestyle of these crabs within the tubes and burrows of worms and decapods such as mud shrimps [50]. Although the crabs from these three subfamilies appear to be morphologically similar, Manning and Felder [51] discuss very slight intraspecific ecophenotypic variation, resulting from the crabs living in burrows from related but separate species of Callianassa mud shrimps. In addition, Palacios Theil and Felder [18] mentioned that the diversity of body shapes is the result of convergent evolution, resulting from host choices, rather than shared synapomorphies. Furthermore, a few non-pinnotherine pea crabs are known from atypical hosts: living inside and on hosts usually inhabited by pinnotherines. Other than their habitat preferences, none of these species resemble pinnotherines in their general morphology.

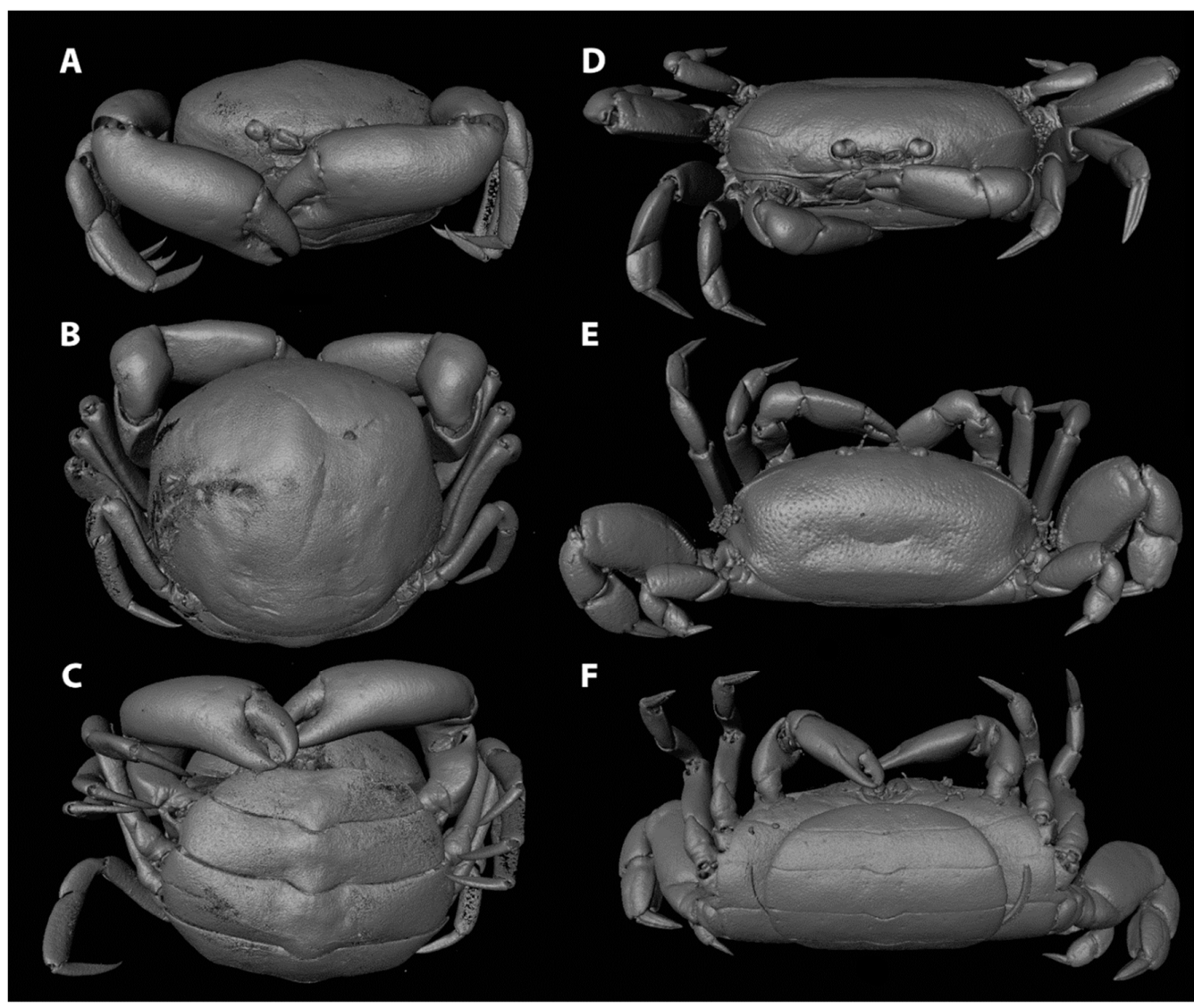

Figure 1. Three-dimensional models of two representatives of Pinnotheridae. (A-C) A typical (female) bivalve- and ascidian-inhabiting pinnotherine, Nepinnotheres pinnotheres (Linnaeus, 1758) (RMNH.CRUS.D.36): carapace width $1.8 \mathrm{~mm}$. (D-F) A typical tube-dwelling pinnixine crab, Pinnixa cyllindrica (Say, 1818) (RMNH.CRUS.D.10104): carapace width $1.5 \mathrm{~mm}$. Videos of the 3D models can be found in the Supplementary Data. 
A few, presumably not closely related, pinnotherine genera share various structural ornamentations on their carapaces. These ornamentations are described in the taxonomic literature as tubercles, plates, lamellae, and upturned margins. The functionality of these ornamentations is still unknown [52], but these structures might be the result of adaptive evolution [27]. Both species of the genus Austrotheres have a subhexagonal carapace shape, with a distinct (in A. pregenzeri) to weak (in A. holothuriensis) epigastric ridge, which is covered with tubercles in A. pregenzeri (Figure 2A) [12]. Members of Durckheimia display two upturned margins: one medial plate and one anterior plate, often with a sharp medial notch, continuing into two lateral margins (Figure 2B) [27,53]. Similarly, crabs of the monospecific genus Visayeres share the medial plate of the supposedly related species of Durckheimia, showing a conical dorsal surface [54]. Members of the genera Serenotheres and Limotheres share a somewhat pentagonal carapace shape, with a pronounced rostrum (more pronounced in Limotheres) and an angled dorsal surface, which forms a weak (Limotheres) or strong (Serenotheres) eave-like (overhanging) structure anteriorly with the 'true' frontal margin that is much lower than the front of the dorsal margin (Figure 2C,D) [27,52,55].

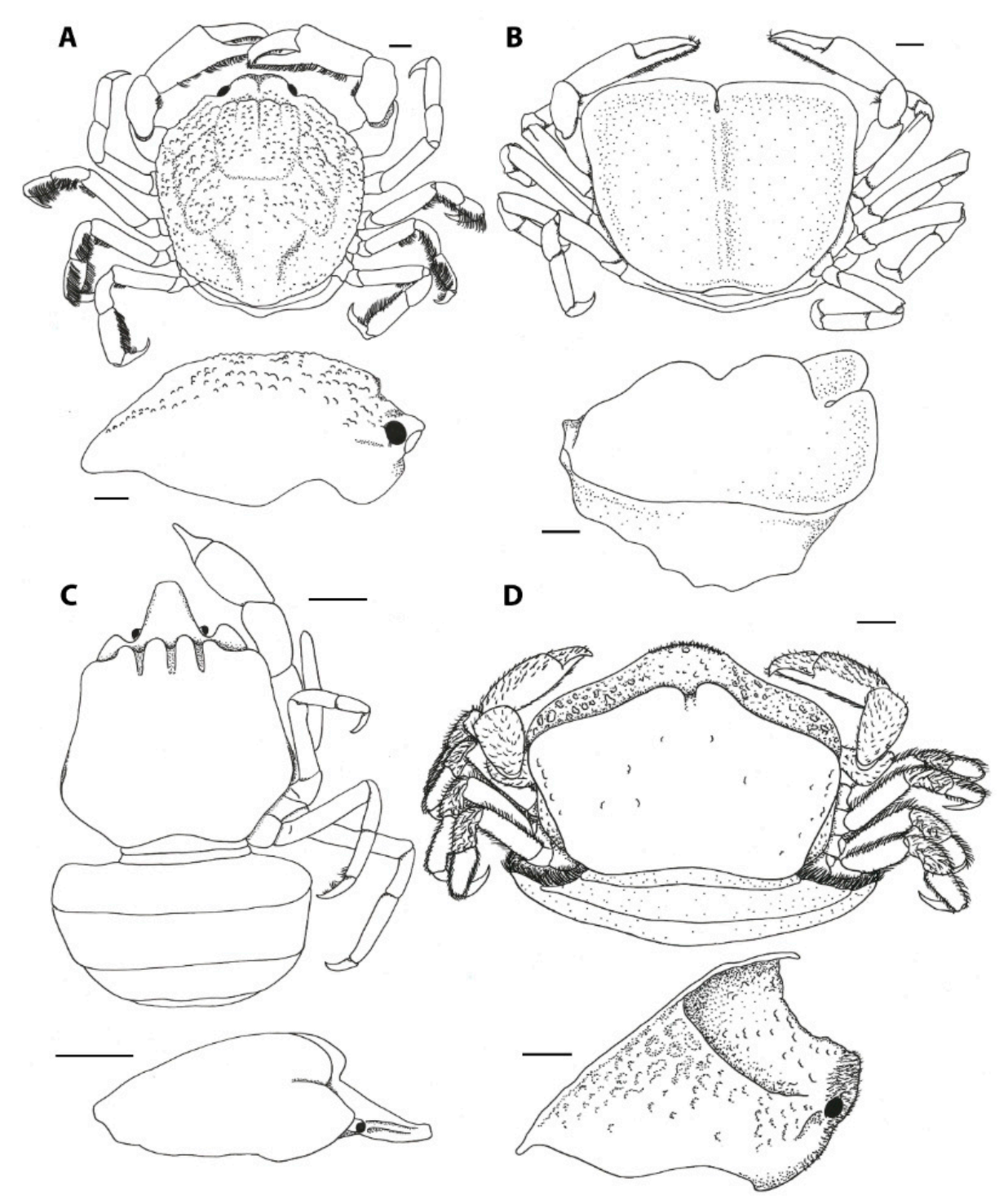

Figure 2. Dorsal and lateral views of representatives of Pinnotherinae with ornamented carapace morphologies. (A) Austrotheres pregenzeri Ahyong, 2018, after Ahyong [12]. (B) Durckheimia lochi Ahyong \& Brown, 2003, after Ahyong and Brown [53]. (C) Limotheres nasatus Holthuis, 1975, after Holthuis [55]. (D) Serenotheres besutensis (Serène, 1967) after Ahyong and Ng [27]. Scale bars: $1 \mathrm{~mm}$. 
Lastly, both members of the monotypic genera Tridacnatheres and Xanthasia share a unique ornamentation of the carapace: a sharp, upturned (in Xanthasia) or weak, folded (in Tridacnatheres) ridge at the carapace margin, which terminates anteriorly in the hepatic region, in addition to a strong (in Xanthasia) or weak (in Tridacnatheres) rostro-dorsal and medial mushroom-like tubercle (Figure 3) [27]. Virtual sections of CT-scan volumes of X. murigera reveal that ornamentations have a well-calcified outer surface, but no associated tissues were identified underneath. The stomach of the crab is partly calcified and is obviously attached to the inner surface of the rostro-dorsal tubercle (Figure 3C). Using this imaging method, no other organs were apparently associated in a similar way with the other ornamental structures. The carapace of Xanthasia (and, to a lesser extent, that of Tridacnatheres) resembles those found in various unrelated leucosiids (purse crabs, such as Alox, Ebelia, and $I x a$ ), hymenosomatids (pillbox crabs, such as Halicarcinus), and epialtids (symbiotic spider crabs, such as Oxypleurodon).

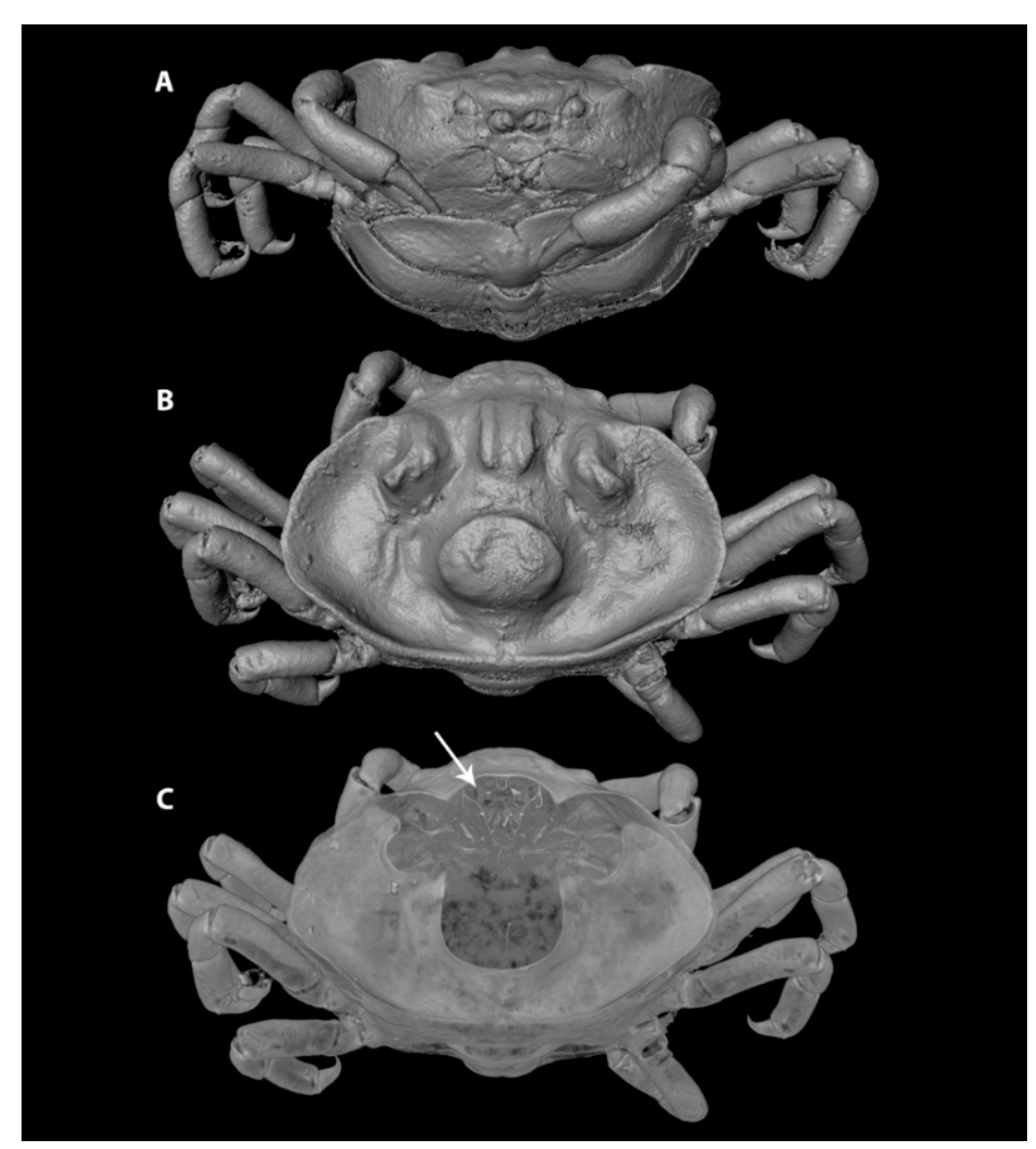

Figure 3. Three-dimensional model of a female Xanthasia murigera White, 1846 (RMNH.CRUS.D.27677): carapace width $1.2 \mathrm{~mm}$. (A) Dorsal view. (B) Lateral view. (C) Volume horizontally cut through carapace showing the stomach inside the most rostro-dorsal tubercle (arrow). Videos of this 3D model can be found in the Supplementary Data.

Although the functionality of this wide range of morphological features is currently unknown, patterns in carapace ornamentation can be linked to host specificity. Most of the above-mentioned species live in various, often spacious, hosts: members of Austrotheres live in holothurians and (large) ascidians, but are known to venture outside their hosts [12]; members of Durckheimia and Limotheres live in scallops of the family Limidae; all species of Serenotheres and Visayeres live inside boring mussels (Lithophaginae); and the members of Xanthasia and Tridacnatheres live inside giant clams (genus Tridacna). The bivalve hosts mentioned above are not necessarily inhabited exclusively by these pea crab genera (see Section 3.6). The unique ornamentations on the carapaces can play parts 
in structural and/or chemical mimicry to confound the host. For example, host mucus may stick to the carapace of the crab easily due to its crevices. Owing to the presence of host mucus on the crab, the crab may not be perveived as a foreign object. While both passive and active mimicry as camouflage have been studied in crustaceans in detail [56], their use of structural and chemical mimicry to avoid being noticed by a host has not received detailed examination hitherto. Other crustaceans possibly utilizing similar strategies might be found in the palaemonid shrimp genera associated with bivalves like Anchistus, Conchodytes, and Pontonia [57]: these genera possess less spines on their carapaces than their ectosymbiotic relatives, probably evolved to be smoother due to their endosymbiotic lifestyle [58]. In addition, cleaning shrimp of the species Ancylomenes pedersoni (Chace, 1958) and other cleaning shrimp symbiotic to anemones might use a similar strategy: in order to not get stung and devoured by the anemone, the shrimps need to acclimate themselves by acquiring host tissue, a phenomenon, which is also well known from clownfish (Amphiprioninae) [59].

The variation in body shape is also translated into the variation of rostrum shape and size. Although the functionality is unknown, species of some pea crab genera possess an elongated rostrum, like Austrotheres [12], Limotheres [55], Serenotheres (e.g., [27]) and, to a lesser degree, in Abyssotheres [60] and Nepinnotheres (e.g., [7]). Members of the (paraphyletic) genus Fabia and the related genus Bonita possess an extension of the rostrum towards the midline of the carapace: two longitudinal sulci split the anterior side of the carapace in three portions [16,61].

Although other symbiotic crab families are known for their host-specific and cryptic lifestyle using camouflage (e.g., Pilumnidae, Eumedoninae, such as Ceratocarcinus, Harrovia, Zebrida) [2,62], most pinnotherines do not display intricate camouflage patterns. Most species have evolved to be clear, transparent or unicoloured (mostly white, yellowish, or brown, purple to black in some species of Arcotheres) [63]. Adult female individuals of some endosymbiotic species are so translucent that the inner organs shine through, most conspicuously the orange-coloured mature ovaries (such as in Nepinnotheres, Pinnotheres, and Zaops) [15,16,33].
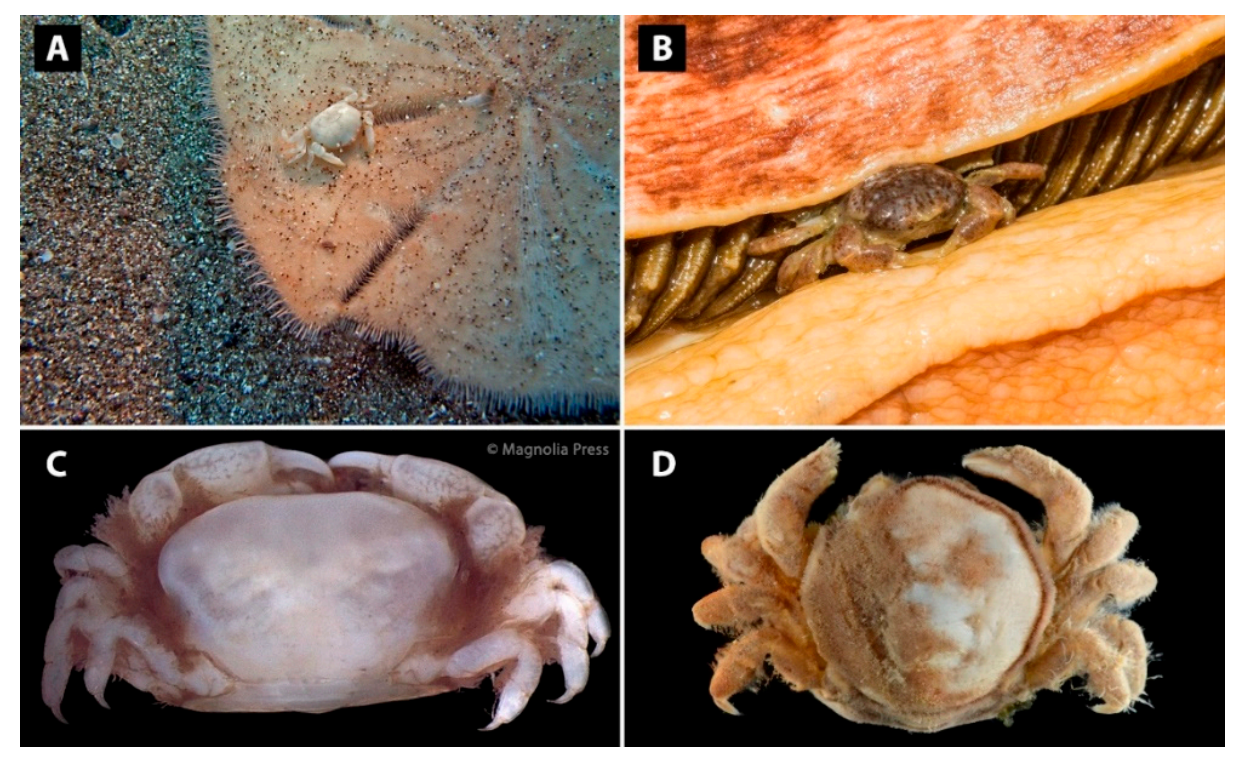

Figure 4. External features of some representatives within the Pinnotherinae. (A) Crypsis of Dissodactylus mellitae (Rathbun, 1900) on a sand dollar (from [64], photo credit M. Faasse). (B) Red-mottled colouration of Opisthopus transversus Rathbun, 1894 living in the folds of a gumboot chiton (Cryptochiton stelleri Von Middendorff, 1847) (photo credit M. Harms). (C) Dense setation at the lateral carapace margins in Holothuriophilus trapeziformis Nauck, 1880 (reproduced from [65]). (D) Overall setation within Nepinnotheres edwardsi (De Man, 1887) (SS-4433), setae removed on the right side (reproduced from The Biodiversity of Singapore database-photo credit: A. Anker). Photographs reproduced with permission from the respective photographers and copyright holders. 
Additionally, males of Nepinnotheres pinnotheres (as Pinnotheres veterum Bosc, 1801) were reported to change their colour at night [66]. A few cases in which crypsis seems obvious, concern the genera Dissodactylus and Clypeasterophilus, which are thought to mimic shell fragments or coral rubble in soft sediments [67]. The white colouration might also mimic shell fragments attached to the host, as some sea urchins (e.g., sand dollars) cover themselves in rubble (Figure 4A; [68]) and some regular echinoids hold debris over their test using tube feet. The Caribbean species Clypeasterophilus rugatus (Bouvier, 1917) even has black-and-white coloured bands on its ambulatory legs [68], similar to Indo-West Pacific Zebrida crabs (Pilumnidae: Eumedoninae) [62]. More elaborate colourations can be found in the males of Pinnotheres bicristatus [33], Pinnaxodes gigas and P. floridensis Wells \& Wells, 1961, and Opisthopus transversus Rathbun, 1894 (Figure 4B) [30]. While the cause or potential function of the colouration in Pinnotheres bicristatus is not mentioned in the description [33], the colouration of the other three species is discussed in taxonomic works. The species display orange-red spots on the dorsal surface of their ambulatory legs and carapace, while the ventral side of these structures display orange-grey spots, which may be caused by carotenes derived from their host [69]. Pinnotheres gigas is known from various geoduck species while $P$. floridensis has only been found in a single species of holothurian. In contrast, $O$. transversus is known from a wide range of hosts, including holothurians (see Section 3.6). Although the species might partly share a similar microhabitat (geoducks siphons somewhat resemble the digestive organs of holothurians) and may have a similar diet (as demonstrated in the third maxillipeds, see below; [30]), this does not fully explain their colouration, because there are other species living inside holothurians with similar mouthparts that lack such colour patterns (e.g., Holotheres). The holothurian-associated pinnixine crab species Pinnixa barnharti Rathbun, 1918, is known to have a similar orange-red colouration, which may also be linked to its diet. This crab species is known to compete with O. transversus for shelter, so probably also for food sources [50].

Setal coverage can be found in many crustacean lineages and, similarly, a wide range in different setal coverage patterns can be found in the Pinnotherinae. Most species are glabrous or only have a sparsely setose integument, in combination with some setae for feeding practises (see below: Sections 3.3 and 3.4). A few exceptions are the conspicuously tomentose holothurian-associated genera Alain, Holotheres, Holothuriophilus (Figure 4C), and Trichobezoares, which possess a very setose carapace or carapace margins $[29,65,70]$. Ahyong [12] mentions that since these genera do not appear to be related, the setation may be an adaptation for holothurian infestation. Few other representatives with setose carapaces belong to Arcotheres (e.g., A. pollus [32]), Afropinnotheres (e.g., A. monodi [7]), Mesotheres (e.g., M. barbatus (Desbonne, in Desbonne \& Schramm, 1867) [71]), Nepinnotheres (e.g., N. pinnotheres, N. edwardsi (De Man, 1887) (Figure 4D), and N. villosulus (Guérin, 1832) [15,72,73]), Pinnotheres (e.g., P. pilulus Tai, Feng, Song \& Chen, 1980 [74]), and Tumidotheres (T. maculatus [75]). The actual function of full or partial coverage with setae remains unknown, but Becker and Türkay [15] suggest that Nepinnotheres pinnotheres uses the short setae to collect mucus from the body walls of ascidian hosts, since it lacks the setal comb on the chelipeds (see below: Section 3.3). Similarly, Kruczynski [75] observed individuals of Tumidotheres maculatus continuously cleaning their carapaces to collect bivalve gill mucus. The setose pinnixine crab Glasella leptosynaptae (Wass, 1968) has been reported from the body of holothurians, with the original description stating that it usually occurs near the anterior end, but never near the mouth of the holothurian. Wass [76] mentioned that the ridges and setae on the carapace may enable the crab to cling to rough-surfaced holothurians, since the crab was always found with its dorsal surface pressed against the body wall of the host [76]. Long setae on the dactylus and propodus of the third maxillipeds of this species indicate a filter-feeding diet, but no observations were made. The full body setation of the previously mentioned pinnotherine species might also play a role in chemical mimicry or defense: host mucus might attach to the short setae in order to conceal the crab, or to make the crab less palatable when venturing outside of the host [77]. 


\subsection{Frontal Appendages and Mouthparts}

The process of host recognition is one of the most studied subjects in symbiotic crustacean research [78]. Studying this process is necessary to understand the evolution, ecology, but also the functional morphology of symbiotic crustaceans. The morphological features thought to be linked to host recognition in pinnotherines are all located anteriorly, namely the eyes for visual cues, and both antennulae and antennae for picking up and emitting chemical cues. The eyes were at first considered to play a role in host recognition; however, the ectosymbiotic Dissodactylus primitivus Bouvier, 1917, was shown to find its host using only chemical cues (see below) [78]. Although related species within the genera Dissodactylus and Clypeasterophilus are known to hop on and off their hosts and are therefore atypical within the Pinnotherinae [79], the lack of functionality of their relatively small eyes remains unexplained [78]. Most pinnotherine species have small eyes, but there is quite a lot of variation in their placement and size, which may be linked to their specific host range (variation in general eye shape can also be found in other symbiotic crustaceans, such as palaemonid shrimp [80,81]). The placement of the eyes and their visibility in dorsal view have been used as taxonomic characters, although size is usually only briefly mentioned. One species stands out, since it hints to evolutionary processes known from animals in caves and deep-sea environments: Arcotheres latifrons (Bürger, 1895) is an eyeless species [19]. Since the host of this species is unknown, it is impossible to say if the host plays a role in the reduction and eventual disappearance of the eyes. The species, however, is known from a single specimen only, which supports the idea that the lack of eyes in this specimen is an anomaly. The larval development of other Arcotheres species has been studied before and no larval stage is known to lack eyes (e.g., [17]).

Species within the Dissodactylus complex are commonly used as model organisms to examine host recognition in pinnotherids [78,82], but more species have been studied in this regard [15]. The antennulae were identified as the principal structures of chemoreception in all studied species $[10,15]$ and no variation among different pinnotherine lineages is known. In addition to the setae on the antennulae, other setae types have a chemoreceptive function in brachyuran crabs as well [83] and male crabs often possess elongated setae near the eyes, such as in Austinotheres angelicus [84] and Dissodactylus primitious [78]. Located near the antennulae are the antennae, which emit chemical (excretory) cues. Some pinnotherine species are attracted to conspecifics (e.g., Tunicotheres moseri (Rathbun, 1918) [15]), which is likely due to chemical cues emitted from the antennal glands (green glands). The morphology of antennae was discussed by previous authors for their supposed taxonomic relevance [71,85].

The third maxillipeds cover the other mouthparts and are also located anteriorly. These structures are thought to play a major role in feeding and are among the most important structures mentioned in studies on pinnotherid taxonomy and evolution. The pinnotherid third maxillipeds evolved to display two distinct features that most other crab families do not display and appear to be heavily modified for symbiotic life [86]: (1) the ischium and merus are fused into an ischiomerus, with a suture only visible in Pinnaxodes (Figure 5A, [87]), but hardely apparent in all other genera; and (2) the dactylus is reduced in various species, leaving a two-segmented palp (Figure 5D, [88]), or dislocated to the base of the propodus forming a 'subchelate' third maxilliped [7]. The features of the third maxilliped have been used as characters to distinguish species and genera $[7,12,27,89]$, but the systematic relevance of the third maxilliped morphology was recently questioned, because of the high intrageneric variation in the genera Nepinnotheres [32], Calyptraeotheres, and Dissodactylus. Additionally, the third maxilliped appears to provide little significance in recognising phylogenetic lineages [85]. The three-segmented palp (consisting of a carpus, propodus and dactylus, articulated with a fused ischiomerus) is known from most genera and is thought to be plesiomorphic. A two-segmented palp (consisting of a carpus and propodus) is known from a few genera (Austrotheres, Calyptraeotheres, Discorsotheres, Dissodactylus, Gemmotheres, Latatheres, Nannotheres, Ostracotheres (Figure 5D), and Tunicotheres) and is thought to be an apomorphic character [12,85]. Additionally, a three-segmented palp has been observed in one 
specimen of Discorsotheres spondyli (Nobili, 1905) (a species with a known two-segmented palp) and is thought to be an anomaly [12].

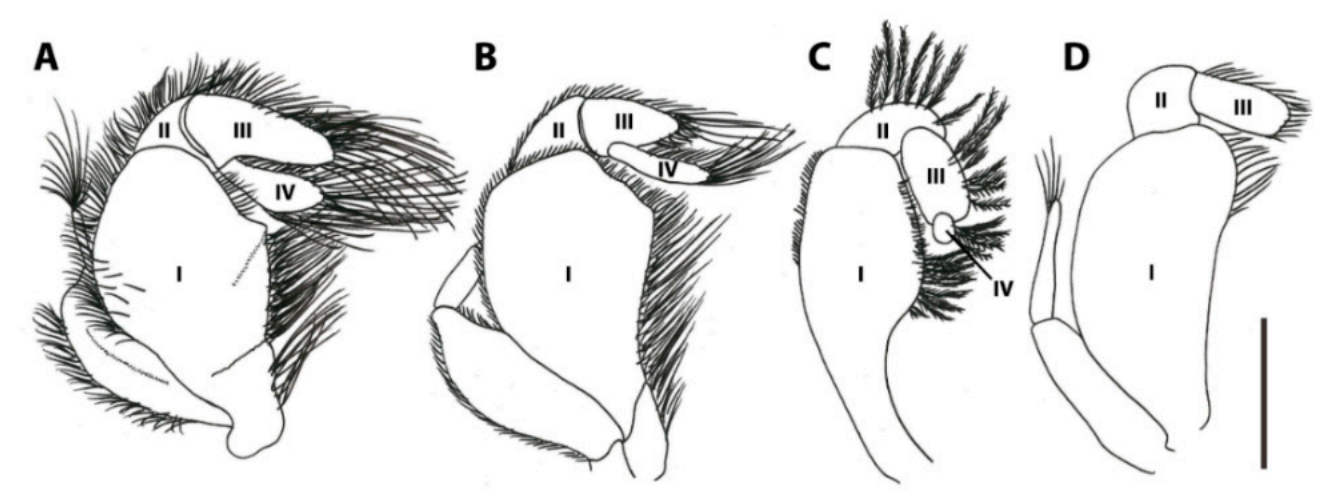

Figure 5. Morphology of the third maxillipeds in pinnotherines. (A) Pinnaxodes floridensis Wells \& Wells, 1961, after Wells and Wells [90]. (B) Afropinnotheres ratnakara Ng \& Kumar, 2015, after Ng and Kumar [91]. (C) Dissodactylus schmitti Griffith, 1987, exopod not illustrated, after Griffith [92]. (D) Ostracotheres cynthiae Nobili, 1906, after Ahyong [12]. Roman numerals indicate different segments: I: fused ischium and merus, II: carpus, III: propodus, IV: dactylus. Scale bars: (A,B,D): $1 \mathrm{~mm}$; (C): $0.5 \mathrm{~mm}$.

Although the palp might not have the once-thought systematic significance [7], it may be relevant for studies focusing on functional morphology. The palps are usually covered with long (feathery) setae and are thought to be used for various feeding strategies: they may be used by bivalve-associated pea crabs, enabling them to grasp host mucus from their own ambulatory legs or chelae, or directly from the hosts' gills [15]. Another strategy would be to filter planktonic food from the bypassing water, as suggested for some holothurian-associated genera (such as Pinnaxodes (Figure 5A), Holotheres, and Holothuriophilus $[41,70,90])$. Species of the bivalve-associated Afropinnotheres are known for their disproportionately large dactyli of the third maxillipeds (Figure 5B) and might use the third maxillipeds in a similar way [7]. Similarly, Christensen and McDermott [23] suggested that pea crabs living in the atrial cavities of ascidians (in this case Pinnotheres pugettensis Holmes, 1900, P. taylori Rathbun, 1918, and Nepinnotheres pinnotheres) use similar strategies for feeding. On the other hand, species of the ascidian-associated Tunicotheres bear no dactyli on the third maxillipeds, so this is likely not the case [88]. The authors also mentioned that immature crabs of Zaops ostreum possess feathery mouthparts and loose them in later stages, while switching feeding strategy (see below: Section 3.4; [23]). Most species within the tube- and burrow-dwelling subfamilies Pinnixinae, Pinnixulalinae, and Pinnothereliinae have extremely long setae on their dactyli of the third maxillipeds, thought to be used for feeding [23]. More evidence for an ecomorphological role of the palp of the third maxilliped can be found in some species lacking a dactylus (or having a seemingly dysfunctional dactylus): species of Dissodactylus and Clypeasterophilus bear very small dactyli on their third maxillipeds (Figure 5C) and are known to feed on the spines and tube feet of their sea urchin hosts (see below), instead of eating planktonic material and/or mucus [93]. Similarly, members of the bivalve-and ascidian-associated Calyptraeotheres and gastropod-associated Orthotheres also appear to possess very small dactyli on their third maxillipeds [92], whereas most other mollusc- and ascidian-associated genera would possess well-developed dactyli.

Pea crabs have a wide range of epipod shapes for internal grooming of the gills, but their morphologies are probably not directly related with their host choice and dietary habits [94]. Pohle [94] found groups of anchor-shaped outgrowths (setules) in setae on the epipods of the maxilla, maxillulae, and maxillipeds, in members of the genera Opisthopus, Dissodactylus, Pinnaxodes, and the unrelated (non-pinnotherine) Pinnotherelia [94]. Pohle did not only study the epipods of pinnotherines, but also the number of gills [95]. Pohle and Marques [95] found that the number of gill pairs in pinnotherid crabs could vary between species, while the number is constant in most other brachyuran 
families. Representatives from the genera Opisthopus, Pinnaxodes, Calyptraeotheres, Tumidotheres, Orthotheres, Tunicotheres, and Nepinnotheres appear to have four pairs of gills, while members of Durckheimia, Ostracotheres, Xanthasia, Limotheres, Arcotheres, and Zaops appear to have three pairs of gills. The genera Dissodactylus, Clypeasterophilus, and Pinnotheres have three or four gill pairs, depending on the species. Pohle and Marques [95] mentioned that this low number of gills is probably the result of a symbiotic lifestyle, rather than the crabs' size: the smaller species within the genus Aphanodactylus (Pinnotheroidea: Aphanodactylidae) were found to have more gill pairs than the larger bivalve-associated pinnotherines.

Although they are seldomly illustrated, the other five pairs of mouthparts (mandibles, maxillae, maxillulae, and first and second pair of maxillipeds) may possess phylogenetically significant anatomical characters (as in palaemonid shrimps [58]). In addition, they may be linked to dietary preferences: symbiotic amphipods appear to have specialised mouthparts, depending on their host and dietary preferences [96]. Similarly, crabs feeding on bivalve mucus may possess other mouthpart characters than crabs feeding on sea urchin spines.

\subsection{Cheliped Morphology}

While crabs from other brachyuran lineages may use their chelipeds for feeding, defense, intraspecific aggression, and/or courtship [83], the chelipeds of pinnotherine species were previously believed to only play a role in feeding strategies [15]. Similar to the morphology of the carapace, the chelae display a wide range of shapes and sizes, including ornamentations like setation and specialised feeding structures. For instance, the relatively largest (relative to body size) and most robust chelae (robustness: chela circumference/length; [97]) can be found in species associated with holothurians and hosts with a similar internal morphology. The robust chelae are most pronounced in members of Austrotheres, Holothuriophilus, Holotheres (Figure 6A), Buergeres, Pinnaxodes, and Trichobezoares (e.g., [30,70]). Similar robust chelae, however, can also be found in the free-living genus Hospitotheres, the tunicate-associated genus Tunicotheres, and a few members of the bivalve-associated genera Tumidotheres and Nepinnotheres $[7,88,98]$. The function of the robust chelae of the before-mentioned genera is not well understood, but the specialised third maxillipeds and position within the host of the holothurian-associated genera (see above: Section 3.2) suggest that the chelae do not play a major role in the feeding strategies [90]. In support of this hypothesis, it is worth noting that Buergeres deccanensis (Chopra, 1931) is known to inflict damage to its host, by piercing the body wall with its chelae while inhabiting the respiratory system [99].

The somewhat robust chelipeds of the species within the ectosymbiotic sea urchin-associated genera Dissodactylus and Clypeasterophilus have been studied in detail [97]. The species within these two genera display a range of different sizes of the chelipeds and morphologies of the cutting edges of both fingers, which is thought to be linked to the dietary habits [97] and the ability to attach themselves to the hosts $[47,100]$. Telford [97] stated that the porosity of the urchin's spines is directly linked to the robustness and cutting morphology of the associated crabs' chelae. For example, the species Dissodactylus mellitae (Rathbun, 1900) possesses very robust chelae, which are perfectly adapted for clipping more porous spines. Another species, Clypeasterophilus rugatus (mentioned by Telford [97] as D. calmani Rathbun, 1918), has comparatively slender chelae, thought to be adapted for feeding on soft tube-feet (podia). Telford [97] mentioned that the most common host of C. rugatus, the echinoid Clypeaster rosaceus (Linnaeus, 1758), is the host with the least porous spines, which are the most difficult to clip. In addition, $D$. primitivus was thought to be the least adapted and most evolutionarily primitive of the studied species [97], and C. rugatus the species with the most derived (or adapted) traits [92], but these hypotheses are rejected in recent molecular analyses [5], placing C. rugatus at a basal position of the clade.

Very slender chelipeds can be found in most of the bivalve-associated genera, reaching most extreme shapes in Amusiotheres (Figure 6B), Durckheimia, Discorsotheres, Solenotheres, and Tacitotheres $[12,19,27,101,102]$.The lack of prominent teeth on the cutting surfaces of the 
chelae, and the elongated mani in most of these species, suggest that chelae are not used for cutting, but for brushing mucus and grooming (e.g., Pinnotheres pisum [15]). A common associated feature with such elongated chelae is a setal ornamentation of the inner surface of the palm and pollex. This brush-like row of setae can be found in female specimens of many genera associated with bivalves: Abyssotheres, Afropinnotheres, Amusiotheres, Arcotheres, Austrotheres, Bonita, Fabia (Figure 6C), Gemmotheres, Discorsotheres, Durckheimia, Latatheres, Nannotheres, Nepinnotheres (but not N. pinnotheres), Pinnotheres (Figure 6D), Sindheres, Tacitotheres, Viridotheres, Visayeres, Xanthasia, Waldotheres, and Zaops $[7,12,15,16,19,27,30,31,54,60,61,102-105]$. This adaptive feature can also be found in two genera associated with gastropods, Ernestotheres and Calyptraeotheres [7,89], and in the sea urchin-associated Dissodactylus latus Griffith, 1987 [93]. After being mentioned in taxonomic papers several times, Becker and Türkay [15] showed the setae row for the first time in detail, using SEM, and found the setae to be of the long regularly orientated pappo-serrate type in Pinnotheres pisum (Figure 6D). The same species was observed and even photographed feeding from strands of nutrient-rich mucus hanging from the gills of their bivalve hosts, using the setal comb. Similarly, the pinnixine crab Scleroplax faba (Dana, 1851) is also known to feed from mucus strands from bivalve hosts, similar to bivalve-inhabiting pinnotherines [50]. This species possesses a setose surface on the inner surface of the chelae, but lacks the specialised setal comb discussed above.
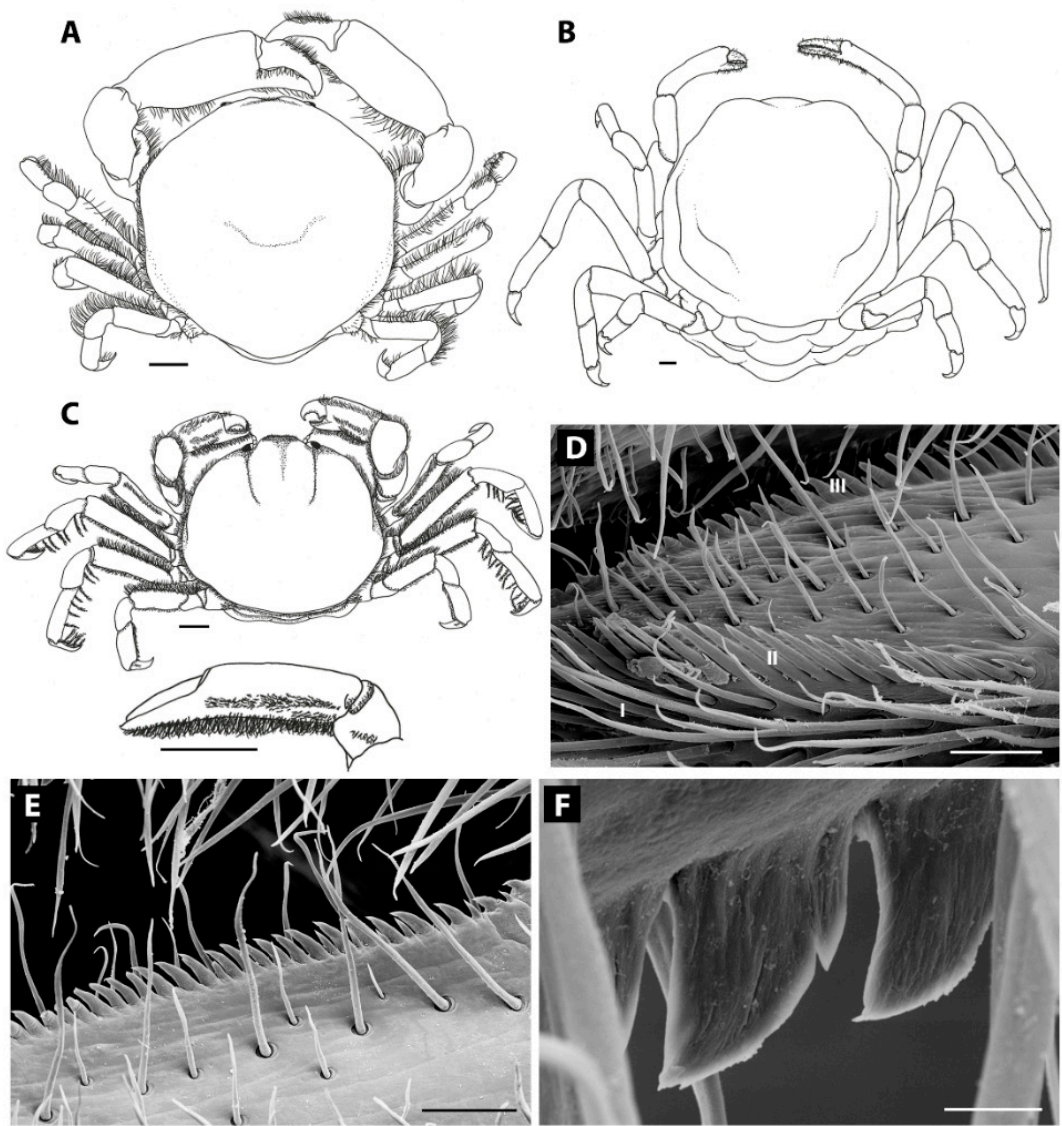

Figure 6. Morphology of the chelipeds and associated ornamentations in pinnotherines. (A) Enlarged chelae in Holotheres danielae Ahyong, 2010, after Ahyong [106]. (B) Amusiotheres obtusidentatus (Tai et al., 1980), after $\mathrm{Ng}$ and Ho [102]. (C) Fabia subquadrata Dana, 1851, note the setal comb on the inner side of the claw, after Campos [16]. (D) Pinnotheres pisum (Linneaus, 1767), note the pappo-serrate setal comb (I), the short row of soft denticles on the inner surface of the pollex tip (II), and the similar denticles on the cutting edges of the claw (III). E: Pinnotheres pectunculi Hesse, 1872, with a row of soft denticles. F: Pinnotheres pectunculi Hesse, 1872, detail of one of the scales, note the rough surface and the serrated tips. Scale bars: (A-C) $1 \mathrm{~mm} ;(\mathbf{D}, \mathbf{E}) 100 \mu \mathrm{m} ;(\mathbf{F}) 10 \mu \mathrm{m}$. 
Additionally, rows of soft denticles, accompanied by soft setae on both sides of the claw, were found on the cutting edges of both the pollex and the movable finger of Pinnotheres pisum [15], P. pectunculi Hesse, 1872 (Figure 6E,F), and Nepinnotheres pinnotheres (Becker, pers. obs.). The mechanical properties of the denticles were revealed during preparation for SEM (Figure 6D-F), as the denticles appeared soft during preparation, making the preservation and study difficult (C.B. pers. obs.). These three species were also found to possess a short row of similar, but longer, denticles on the inner side of the tip of the pollex (Figure 6D). A quick survey of the available taxonomic literature reveals more species that possess the small denticles on the cutting edges of the chelae: Pinnotheres haiyangensis Shen, 1932, P. dilatatus Shen, 1932, and P. luminatus Tai et al., 1980, were all illustrated by Tai and Yang [74] with small denticles on the inner surface of both the pollex and the movable finger. More recently, Sindheres karachiensis Kazmi \& Manning, 2003, was illustrated and described with special attention to the denticles, looking similar to those mentioned above [105]. A thorough survey of these and other species is needed to confirm if the row of denticles is homologous to the row found in Pinnotheres pisum, P. pectunculi and Nepinnotheres pinnotheres, and whether this character is present in more pinnotherine species. The function of these denticles is not known, but the position and the softness of the structures suggest that they are not used for scraping host mucus (C.B. pers. obs.). The soft denticles might, however, play a role in chemoreception, where the crabs use their chelae's soft denticles to 'taste' their food before digesting it. Similar soft denticles can be found in many more crab species and this feature is not limited to pinnotherids (C.B. pers. obs.). The denticles in the studied pinnotherids can be observed to have a rough surface and serrate tips, potentially bearing pores similar to the ones found on the chelae of the hermit crab Pagurus hirsutiusculus (Dana, 1851) [107]. This row of denticles resembles structures found on the first chelipeds of some palaemonid shrimp species, living in association with bivalves and ascidians (C.H.J.M. Fransen, pers. comm.).

\subsection{Ambulatory Leg Adaptations}

In all symbiotic brachyuran crab lineages, most adaptive features can be found in the morphology of the ambulatory legs [2]. A few examples are the last pair of ambulatory legs of sponge crabs (Dromiidae) and carrier crabs (Dorippidae), the subchelate ambulatory legs of zebra crabs (Pilumnidae: Eumedoninae), and flexible dactylo-propodal articulation of coral-clinging crabs (Tetraliidae) [2]. The Pinnotheridae form no exception, since the most apparent feature of the tube-dwelling pinnixine, pinnixulaline, and pinnothereliine crabs are the wide third pair of ambulatory legs for gripping the walls of shared burrows and tubes [18]. The Pinnotherinae have more subtle morphological adaptations of the ambulatory legs, which are discussed below.

The most apparent ontogenetic changes can be seen in the morphology of the ambulatory legs. In both reproductive strategies [8], the hard stage males possess long plumose swimming setae, usually on the second and third ambulatory legs (e.g., described from Pinnotheres pisum [108] and Zaops ostreum [109]). The hard stage crabs swim between hosts and use their long setae for swimming by "bending their chelae slightly inward and by holding the first and fourth ambulatory legs stationary in an inverted V-shape, and by fast stroking both sides of the second and third ambulatory legs back and forth sequentially" [110]. In some species, swarming of post-hard staged males and females is known, even after the initial infestation. In this case, the crabs also develop new swimming setae (known from members of Calyptraeotheres [9], Tumidotheres (Figure 7A) [8,30], Austrotheres [12], Fabia [45], and seemingly from species of Afropinnotheres [7], Ostracotheres [12], Nepinnotheres [32], and Pinnotheres [110]). In addition, some species are known to develop similar secondary swimming setae, but in a later moulting stage: Watanabe and Henmi [17] found that one female crab (an unidentified species within the genus Arcotheres) developed swimming setae in a post-hard stage, after forming simple setae at first. A similar development was found in post-hard stages of Pinnotheres pisum [111], but the author does not mention whether the setae are of simple or plumose type [17]. The secondary development of plumose swimming setae in post-hard stages might be a strategy for crabs to leave their host when circumstances are unfavourable (e.g., when starving; [17]). 


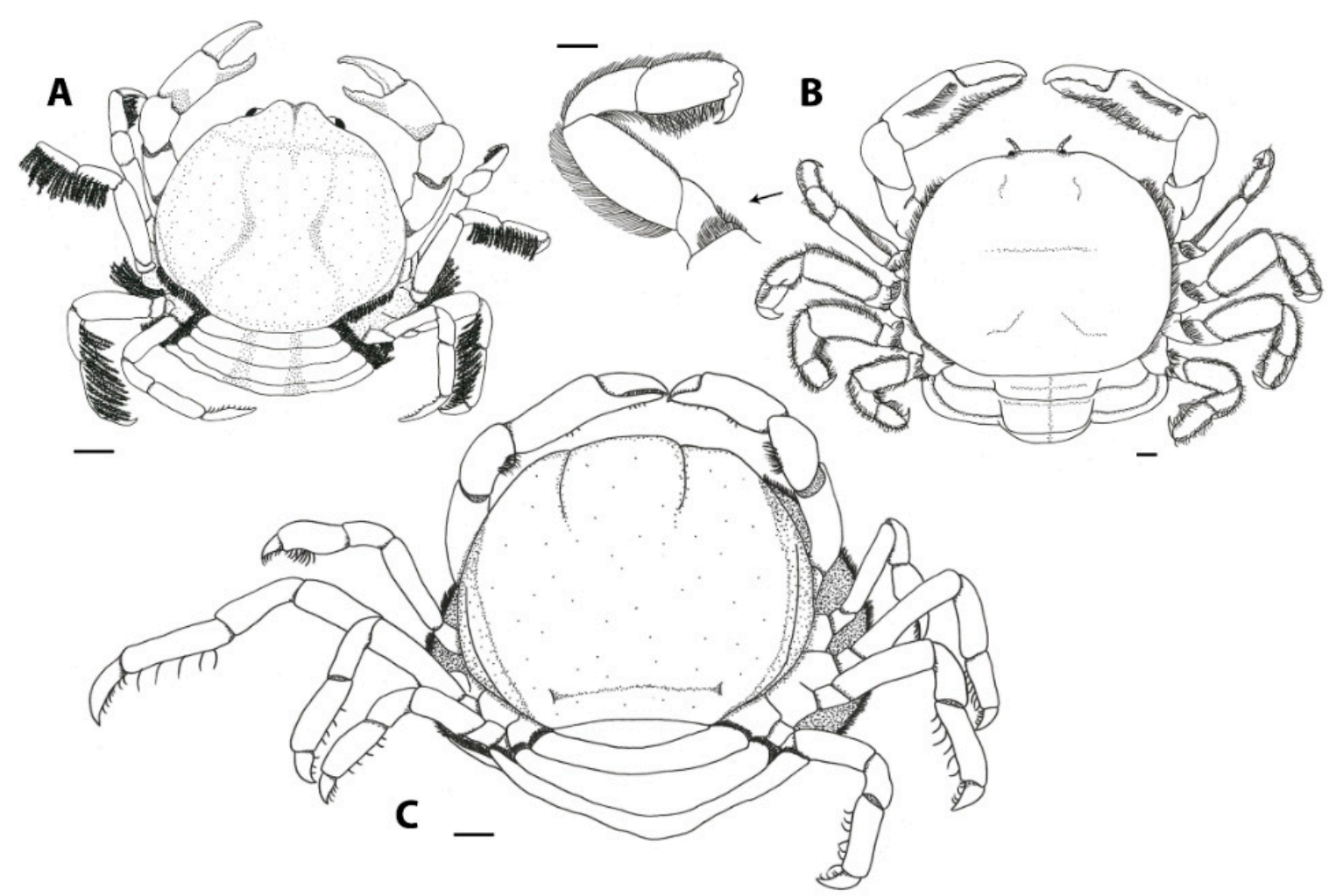

Figure 7. Morphology of the ambulatory legs in pinnotherines. (A) Tumidotheres margarita (Smith, 1869), after Campos [8]. (B) Ernestotheres conicola (Manning \& Holthuis, 1981), note the flattened ambulatory legs, after Manning [7]. (C) Fabia carvachoi (Campos, 1996), after Campos [16]. Scale bars: (A-C) $1 \mathrm{~mm}$.

Similar to the overall shape and size of the chelipeds, the ambulatory legs of pinnotherines also display a wide range of shapes and sizes. The widest legs among pinnotherines, just like the most robust chelae, are again found in holothurian- and geoduck-associated genera like Pinnaxodes and Holothuriophilus [30]. Members of the gastropod-associated genera Mesotheres, Ernestotheres (Figure 7B), and to some extent Orthotheres, have flattened, broad ambulatory legs [7,71,112], probably to cling to their large, mobile hosts. In contrast, members of Waldotheres, Amusiotheres, Tacitotheres, Zaops, and most other bivalve-associated genera have elongated, slender, and feeble ambulatory legs. This indicates that they do not leave their sedentary host, and rarely move around within the host [8]. Members of Zaops might form an exception in having swollen propodi of the ambulatory legs, similar to the ambulatory legs of Raytheres [84]. It remains unknown whether the swollen propodi are an adapted feature.

The different sizes of ambulatory legs in pinnotherines have also been studied in detail, with special focus on the elongation of just one leg after the hard stages [113-117]. This asymmetry of the ambulatory legs is thought to be linked to the feeding habits and the initial settlement of the female crabs inside the host [15]. In laboratory experiments, Watanabe and Henmi reared a member of the genus Arcotheres and found that the longer ambulatory leg of this species developed on the side of the crab which was directed to the opening of the bivalve host (Watanabe and Henmi, pers. comm. in [15]). While the elongation of the single leg segments may vary between species and genera, in most cases, the dactylus and propodus of the elongated ambulatory leg possess morphological adaptations, seemingly for 'reeling in' mucus strands (discussed below), similar to the modified cheliped mentioned above. Asymmetry of the ambulatory legs is not limited to, but is most apparent in the bivalve-associated genera Amusiotheres, Discorsotheres, Fabia (Figure 7C), Solenotheres, Tacitotheres, and Zaops [12,71,116]. Extremely asymmetrical legs can also be found in the limpet-associated Enigmatheres [61].

Most variation in the ambulatory legs can be found in the most distal segment, the dactylus. For instance, the previously mentioned ectosymbiotic genera Dissodactylus and Clypeasterophilus have bifurcate ('forked') dactyli in their first, second, and third pair of ambulatory legs (Figure 8C), which are 
thought to aid in moving between the spines of their host urchins and sand dollars $[20,92,100,118]$. Similarly, one species within Abyssotheres (A. abyssicola (Alcock \& Anderson, 1899)) has an "obtuse projection on the dorsal surface of the dactylus of the walking legs", but this seems to be a unique feature, even within the genus [119]. Morphological adaptations in the dactyli of other species can also be linked to their host choice and position inside the host: the holothurian-associated Holotheres halingi [120] and its congeners possess falcate, sharp dactyli in all ambulatory legs, used to cling to the inner surface of the host. The description of Holotheres halingi mentions the species to be favouring lateral contact more than bottom contact, and the species seems to be unable to walk due to its enlarged pleon and modified ambulatory legs [120]. Morphologically similar falcate dactyli can be found in a wide range of pinnotherine genera, not limited to holothurian symbionts: Discorsotheres, Durckheimia, Latatheres, Orthotheres, Ostracotheres, Serenotheres, Solenotheres, Tridacnatheres, Visayeres (Figure 8A), Xanthasia, and some species of Nepinnotheres [12,19,27,54,101].
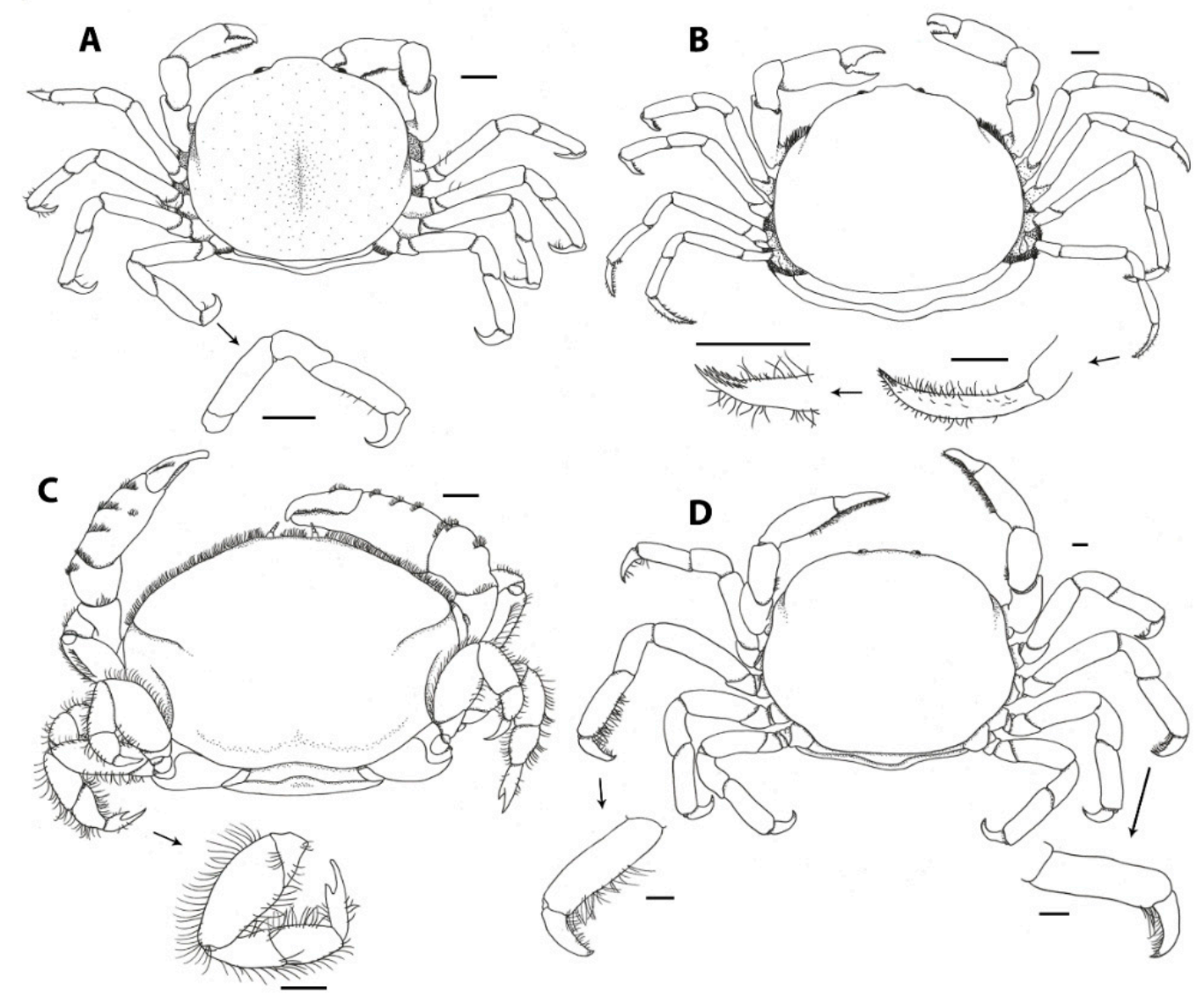

Figure 8. Morphology of the ambulatory legs and dactyli in pinnotherines. A: Visayeres acron Ahyong \& Ng, 2007, with falcate ambulatory leg dactyli, after [54]. B: Arcotheres similis (Bürger, 1895), with sword-shaped last ambulatory leg dactyli, with microstructured dactylus tip, after [19]. C: Dissodactylus schmitti Griffith, 1987, with bifurcate second and third ambulatory leg dactyli, after [93]. D: Discorsotheres spondyli (Nobili, 1905), with asymmetrical setation on the propodus and dactylus of the second pair of ambulatory legs, after [12]. Scale bars: (A-D) $0.5 \mathrm{~mm}$.

Members of the bivalve-associated genus Arcotheres are unique with regard to a few morphological features [115], most obvious in the form of the dactyli of the last pair of ambulatory legs. The dactyli are described as 'sword-shaped' [115], being straighter and more elongated (longer or of equal length as the attached propodus) than the dactyli of the other ambulatory legs (Figure 8B) [19]. The dactyli of the last pair of ambulatory legs are often ornamented with rows of short, simple setae (e.g., A. ridgewayi 
(Southwell, 1911), illustrated in [121]) and a row of denticles (e.g., most conspicuous in A. placunae (Hornell \& Southwell, 1909), illustrated in [122], and A. vicajii (Chhapgar, 1957) [123]).

The functions of these setae and denticles are not known, but since the last pair of ambulatory legs is generally shorter than the third pair in Arcotheres, it is improbable that crabs use these legs to 'reel in' host mucus. The denticles, however, resemble those on the chelipeds' cutting edges mentioned above (see Section 3.3), and may be used to scrape or groom their host, or even their own bodies for gathering mucus: some species are illustrated with their last pair of ambulatory legs being folded up against the dorsal side of their carapace (e.g., A. borradailei (Nobili, 1906) [121]). In addition, the denticles might be used for chemoreception, by 'tasting' food with its ambulatory legs, as oberved in Zaops ostreum [109], or for providing grip inside the host: similar rows of scales can be found on the dactyli of the ambulatory legs of some palaemonid shrimp species, also living in bivalves and ascidians $[57,58,124]$. Furthermore, all members of the gastropod-associated Calypraeotheres, except C. garthi, also possess sword-like, setose dactyli on their last ambulatory legs [89,125-128]. The function and microstructure of the appendages remain unknown. Moreover, some species of Pinnotheres also possess a similar dactylus on both their last ambulatory legs (see Section 3.6).

In addition to Arcotheres and Calyptraeotheres, species in many other genera possess inconspicuous ornamentations on their leg segments, but the arrangement may vary between genera. For example, simple setae are found on the dactyli of the fourth ambulatory legs of species within Gemmotheres and Tunicotheres [88], and similar setae are found on the propodus and dactylus of members of the genus Discorsotheres, with some species even showing asymmetry between the leg setation (Figure 8D) [12]. The functionality of this specific setation is probably linked to the feeding strategy of these species, although this has only been observed in Zaops ostreum $[23,109]$. The observed crabs feed in a similar way as Pinnotheres pisum [15] by gathering mucus strings, but Stauber [109] observed that they "catch newly formed mucus with the (distally setose) ambulatory legs, then reach underneath the pleon with their chelipeds, comb the legs, and pass the food on to the mouth" [23].

The detailed illustrations and ecological information provided by Zmarzly [50] allow for a quick survey of the potentially adapted morphology of symbiotic pinnixine species. Both the pinnixine crab species Scleroplax faba and S. littoralis (Holmes, 1895) are known as endosymbionts in holothurians and bivalves respectively, and possess falcate dactyli on their ambulatory legs, thought to aid in attaching themselves to their host. Scleroplax faba also appears to possess uniform ambulatory leg lengths, atypical for members of the Pinnixinae, Pinnothereliinae, and Pinnixulalinae.

\subsection{Sexual Anatomy and Larval Characters}

The reproductive strategies of Pinnotherinae, their larval development and sexual anatomy show several traits that seem important with regard to their symbiotic lifestyle. It is, however, hard to distinguish between adaptations that are characteristic for small-sized crabs in general and those that are specific to symbiotic lifestyles. Hines [129] has shown that the investment in egg production (body weight/brood weight) in Zaops ostreum (as Pinnotheres ostreum) and Fabia subquadrata is highly increased compared to free-living crab species. Hartnoll [130] reviewed the reproductive investment among a range of brachyuran crabs and concluded that metabolic costs drive trade-offs between growth (body size) on the one hand and reproductive investment (relative brood size) on the other. A large body size reduced the risk of predation, but may lead to reaching sexual maturity later in ontogeny and, also, to producing smaller broods (in relation to body size) as more energy resources go into growth [130]. Female bivalve-dwelling pinnotherines with a life cycle similar to Pinnotheres pisum, remaining solely within their host after starting metamorphosis, are not exposed to predators. Such species can, thus, 'afford' to invest a greater deal of energy resources in reproduction. By not being very mobile, they also save on metabolic costs for locomotion and do not need to search for food as they directly obtain it from their host.

Egg production, however, is also constrained by female body size in general and particularly by the space that is available for yolk accumulation inside the body. This may explain that pinnotherids, 
despite being generally small in order to be able to enter and fit inside their hosts, have a preference for large- over small-sized host species within their specific host range, as the same species reaches larger body sizes in more spacious hosts [15]. This again has an effect on the fecundity (eggs per brood) which is positively correlated with body size (carapace width) within a species (e.g., Dissodactylus primitivus, D. crinitichelis Moreira, 1901 [131]; Austinotheres angelicus [40]).

Another important adaptation regarding brood size is the large pleon of female pinnotherids which functions in incubating the eggs until larvae hatch. The pleon is extremely enlarged in bivalve-associated Pinnotherinae resembling Pinnotheres pisum: the pleon covers the whole ventral side of the crab, reaches the mouthparts anteriorly and even covers the proximal segments of the ambulatory legs [132]. In fact, the pleon is enlarged to a degree that it seriously hampers locomotion of adult female P. pisum (C.B., pers. obs.). Due to spending their whole adult life inside the host, where females are protected from predators and have plenty of food, locomotion is not crucial for survival. A comparison of brood sizes (mass of brood and number of eggs), pleon width, and body size (body mass and carapace width) among various species may yield insights into the degree of reproductive investment, and the adaptations in relation to different hosts and life history strategies of Pinnotherinae. Unfortunately, the current knowledge on pleon sizes among pea crabs is very limited as no study has focused on this character so far, and only few taxonomic descriptions show the female in ventral aspect or details of the pleon in the presented line drawings (but see Pinnaxodes floridensis [90]). It is, however, obvious that the female pleon of ectosymbiotic pinnotherine genera (Dissodactylus and Clypeasterophilus) is not as wide as in most endosymbiotic taxa. As in all brachyuran crabs, a sexual dimorphism in pleon width is also obvious in these genera, with the male having a narrow pleon and the female possessing a wide pleon for breeding. The female pleon in Dissodactylus and Clypeasterophilus is, however, not enlarged to a degree that it is visible from the dorsal view [133] and does not appear to prevent locomotion. The members of the ectosymbiotic genera need to retain the ability to move around on the host and escape predators.

Although the size relations and the outer morphology of the pleon have barely been studied, the internal morphology has caught interest in the past. In most brachyuran crabs, the ovaries are restricted to the cephalothorax and do not extend into the pleon [134]. In the bivalve-dwelling Pinnotheres pisum and P. pectunculi, and the ascidian and bivalve-dwelling Nepinnotheres pinnotheres, ovaries extend into the pleon and run along both sides of the digestive system [135]. To date, it is unknown which other pinnotherine genera show the same extension of ovaries, but it is very likely the case for many endosymbiotic species with an extremely wide pleon. A study of male P. pisum and N. pinnotheres has shown that a corresponding adaptation is present in males: parts of the vas deferens, where gametes develop and seminal plasma is produced, reach into the narrow male pleon as well [136]. This shows that the large size of the female pleon alone may not explain the adaptation of extending reproductive organs beyond the cephalothorax.

Interestingly, another symbiotic group of crabs shows the same adaptation as Pinnotherinae, at least in the females: several species of Cryptochiridae (gall crabs) associated with stony corals have ovaries extending into the pleon to a varying degree [137]. Also, in the free-living mangrove crab Goniopsis cruentata (Latreille, 1803), mature ovaries extend into the first pleomers [138]. This species is relatively small sized with females reaching maturity $\left(\mathrm{L}_{50}\right)$ at $22.6 \mathrm{~mm}$ carapace width [139]. The trait of reproductive organs being extended from the cephalothorax into the pleon shows how hard it is to identify the responsible driver for evolutionary changes. Small body sizes and symbiotic/parasitic lifestyles similarly lead to peculiar sexual adaptations and an increase of the investment in reproduction $[140,141]$. Most endosymbionts have smaller body sizes than their free-living relatives, thus, adaptations cannot be linked to body size or symbiotic lifestyle alone.

Other characters which may have significance with regard to the pinnotherid's symbiotic lifestyle can be found in the larval development and morphology: most brachyuran zoea larvae possess paired lateral spines, and a dorsal and rostral spine [142], which are either regarded as buoyancy structures for planktonic dispersal or as an antipredatory adaptation. Within the Pinnotherinae, 
larvae of Pinnaxodes chilensis (H. Milne Edwards, 1837) [143], Clypeasterophilus rugatus [144], Nepinnotheres pinnotheres (as Pinnotheres veterum Bosc, 1801) [145], and Afropinnotheres monodi [146] also possess these spines, and confirm to the general brachyuran larval morphology. Several other species and genera of Pinnotherinae are known to lack the dorsal spine, such as Pinnotheres pisum and P. pectunculi [132], some are even completely spineless (e.g., Zaops ostreum [147]).

In the latter species, behavioural experiments revealed a specific behaviour when exposed to predators: zoea larvae of $Z$. ostreum, quickly sank to the sea floor when the pleon was flexed tightly against the body [147]. This behaviour was interpreted as an antipredatory defense [147], but may also have benefits for pea crab larvae settling in a habitat with suitable hosts or in a large aggregation of hosts as in mussel or oyster beds. It it worth noting that pinnotherines are not the only group in which some species show a reduction of spines in zoeal stages; this adaptation is also found in species of Leucosiidae and Hymenosomatidae [142,145], and may have evolved for similar reasons, either as an antipredatory strategy or for the control of larval settlement in suitable habitats (in both cases by being able to sink faster and more directional).

Some species of Pinnotherinae show an abbreviated larval development or even parental care. The larval development tends to be abbreviated in pinnotherines, by having only two to four zoeal stages, while most brachyuran crabs have five. In Tunicotheres moseri, symbiotic with ascidians [148], and Mesotheres barbatus (as Orthotheres barbatus (Desbonne in Desbonne \& Schramm, 1867) [149]), only two zoea stages were found. Tunicotheres moseri also shows brood care: after the larvae hatch from the eggs, they are not dispersed, but remain under the female pleon until they reach the first crab stage [150].

\subsection{Updated List of Symbiont-Host Associations}

Updated symbiont-host association list for all recognized (valid) species within the Pinnotherinae are showed in Table 1. 
Table 1. Updated symbiont-host association list for all recognized (valid) species within the Pinnotherinae (previous lists include [11,26,151]). Pinnotherine taxonomy follows WoRMS [4] and the Systema Brachyurorum [3], unless stated otherwise in the subscripts (see below). References including the most complete information about host specificity can be found for all species. If recent works list new host species, but neglect the already known hosts from older literature [6], both the older and more recent references are included. Host nomenclature follows identifications provided in the references, also updated with WoRMS [4]. Where host groups or host species are unknown, a question mark is provided; where identifications of host species were unable to link with a recognized species, identifications are provided with a question mark between parentheses: (?). Notes on the host specificity or taxonomy can be found below, indicated with superscript numbers. Distribution abbreviations: IWP-Indo-West Pacific, EP-East Pacific, ATL-Atlantic Ocean (please note that Atlantic and East Pacific distributions also include non-tropical waters).

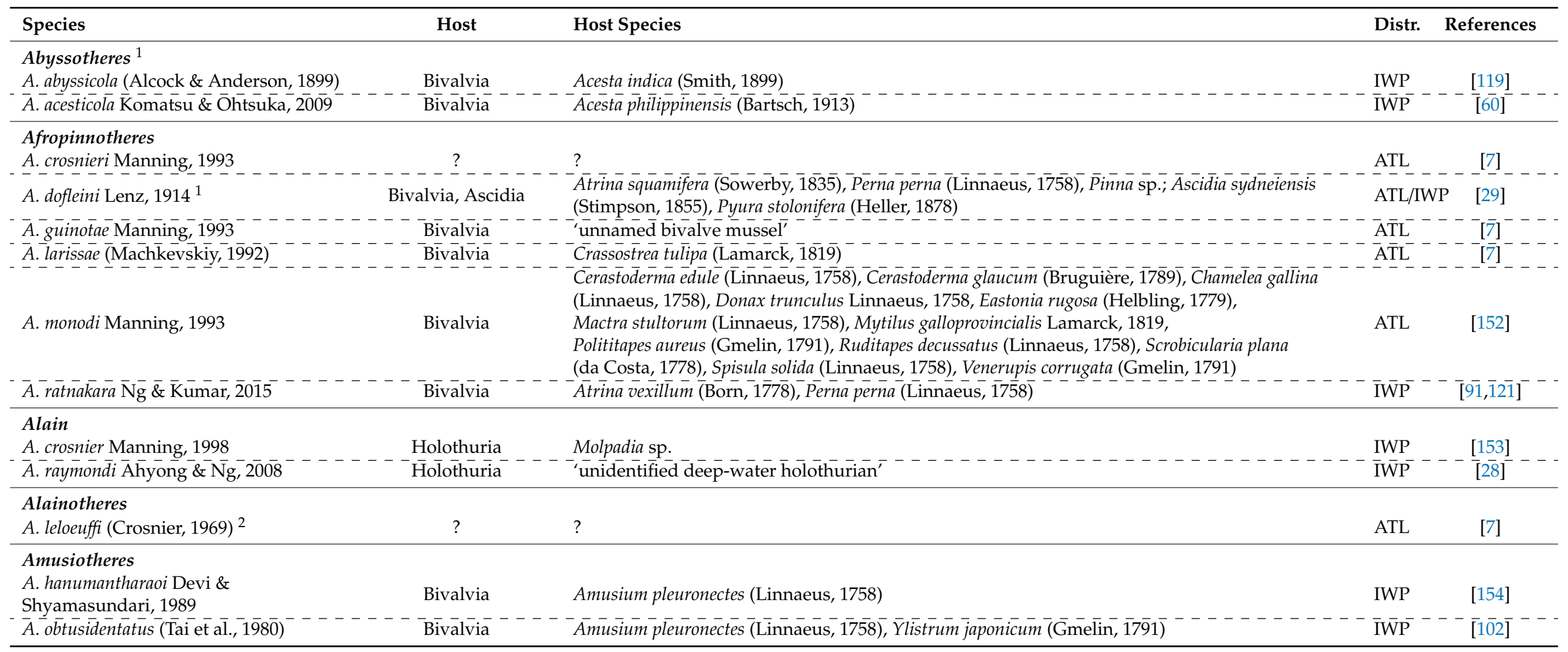


Table 1. Cont.

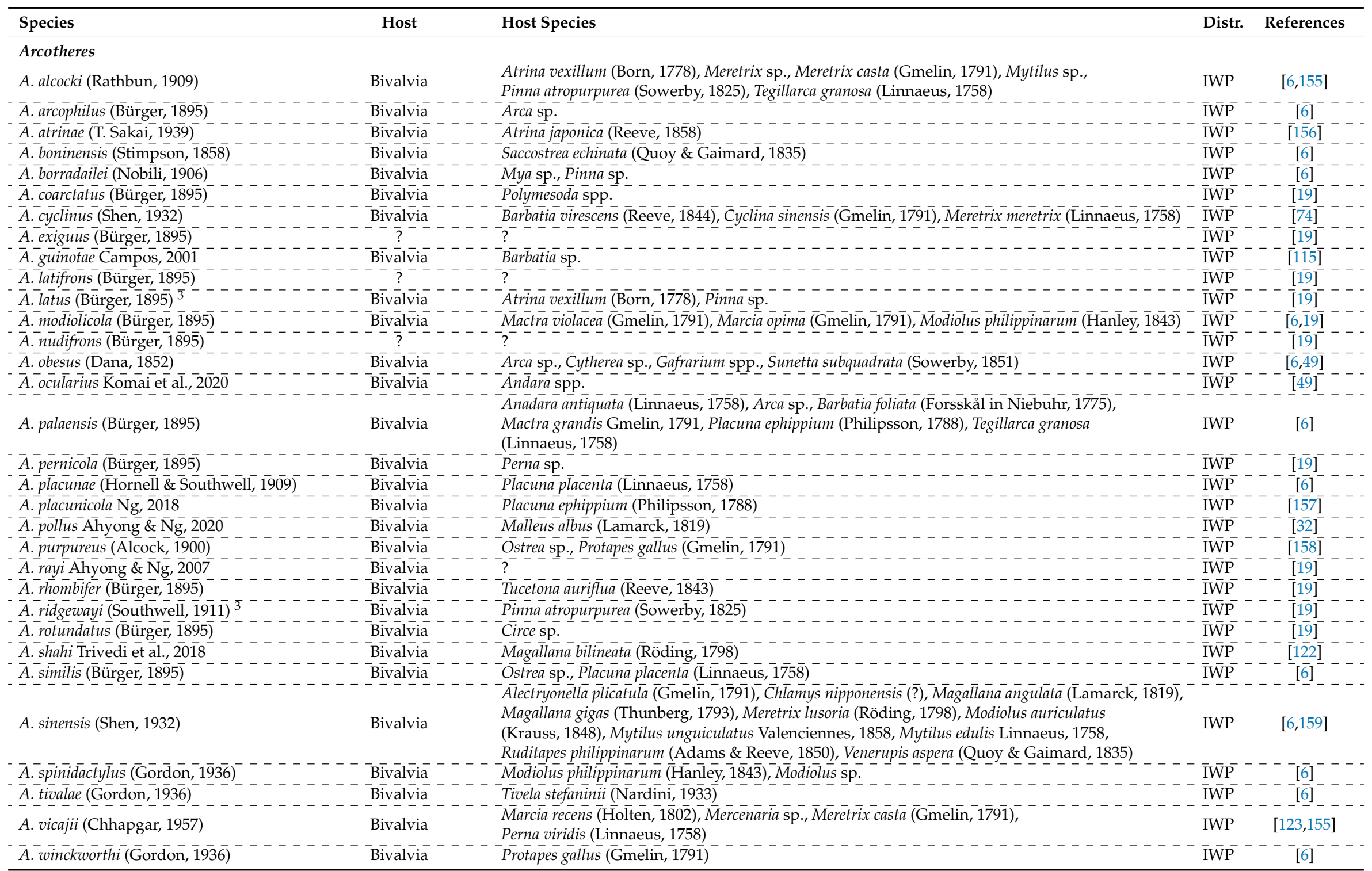


Table 1. Cont.

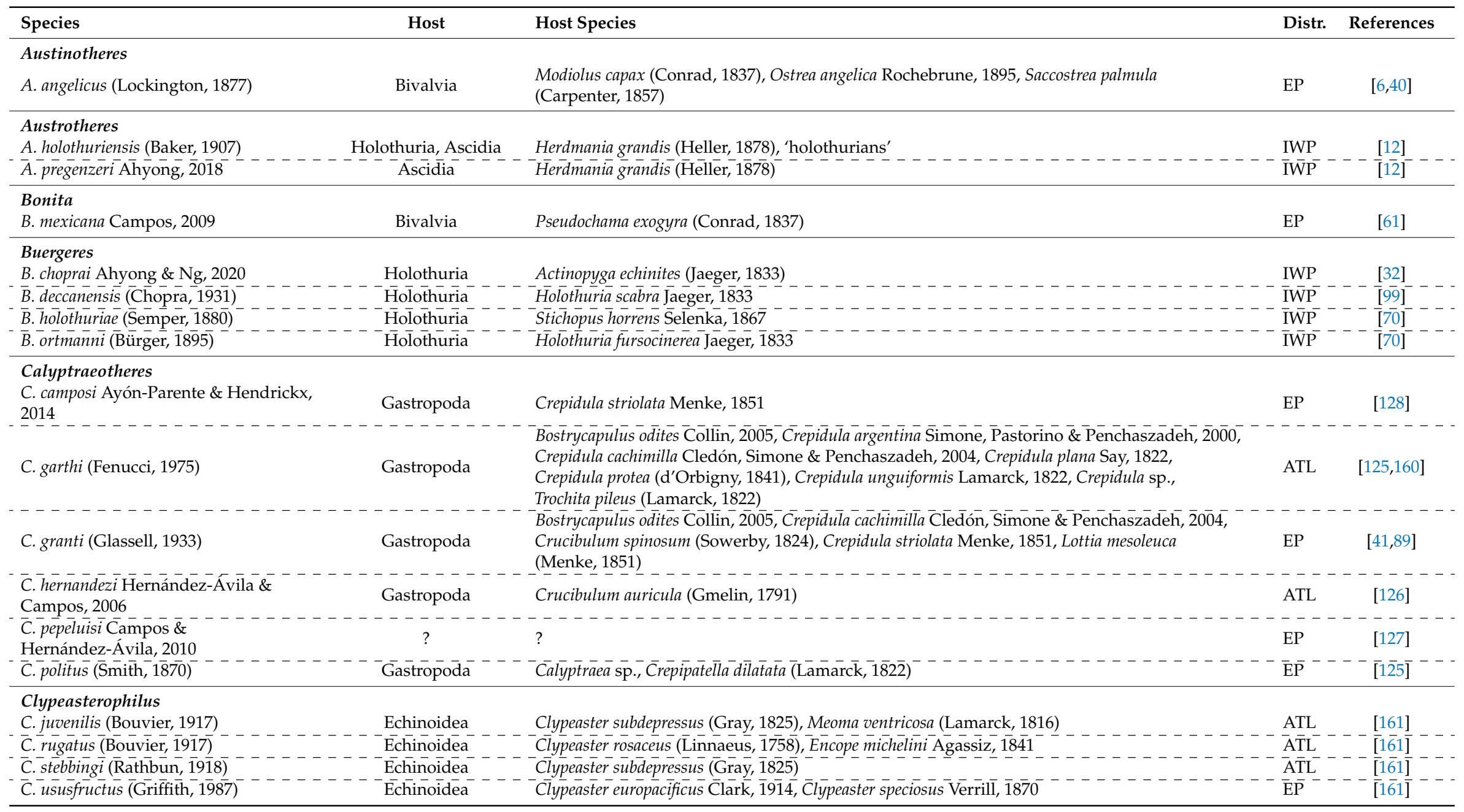


Table 1. Cont.

\begin{tabular}{|c|c|c|c|c|}
\hline Species & Host & Host Species & Distr. & References \\
\hline \multicolumn{5}{|l|}{ Discorsotheres } \\
\hline D. camposi Ahyong, 2018 & Bivalvia & Spondylus spp. & IWP & [12] \\
\hline 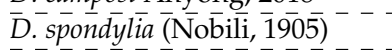 & B̀ivàlviāa & Spondy $\bar{l}$ us exilis cf. (Sowerby, $\overline{1} 8 \overline{9} 5)$ & $\overline{\mathrm{I}} \overline{\mathrm{W}} \mathrm{P}$ & $\overline{1} \overline{2}]^{-}$ \\
\hline D. subglobosus (Baker, 1907) & Bivalvia & 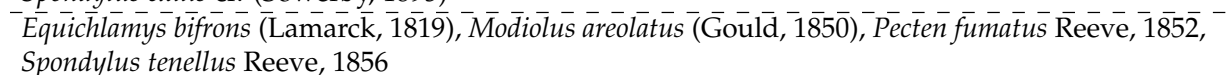 & IWP & {$[12]$} \\
\hline 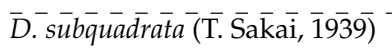 & B̀ivālviāo & 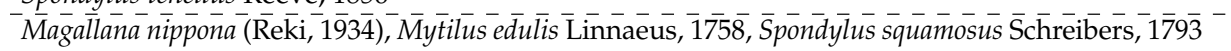 & $\overline{\mathrm{I}} \overline{\mathrm{W}} \overline{\mathrm{P}}$ & {$[1 \overline{2}]$} \\
\hline \multicolumn{5}{|l|}{ Dissodactylus ${ }^{4}$} \\
\hline D. crinitichelis Moreira, 1901 & Echinoidea & $\begin{array}{l}\text { Clypeaster rosaceus (Linnaeus, 1758), Clypeaster subdepressus (Gray, 1825), Encope emarginata } \\
\text { (Leske, 1778), Encope michelini Agassiz, 1841, Leodia sexiesperforata (Leske, 1778), }\end{array}$ & ATL & [161] \\
\hline D. glasselli Rioja, 1944 & Echinoidea & 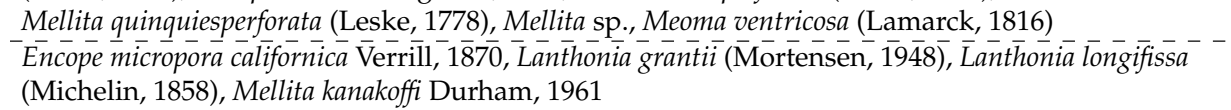 & EP & {$[161]$} \\
\hline D. latus H. Griffith, 1987 & Echinoidea & 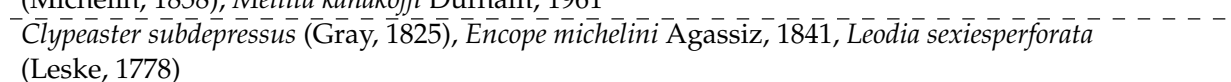 & ATL & [161] \\
\hline D. lockingtoni Glassell, 1935 & Echinoidea & $\begin{array}{l}\text { Encope grandis Agassiz, } \overline{1} \overline{84} \overline{1}, \bar{E} \text { Encope micropora californica Verrill, } \overline{1} 8 \overline{7} 0, \bar{L} \text { Leodia sexiesperforata }-\overline{-} \\
\text { (Leske, 1778), Encope spp., Lanthonia grantii (Mortensen, 1948), Lanthonia longifissa } \\
\text { (Michelin, 1858), Mellita kanakoffi Durham, } 1961\end{array}$ & $\mathrm{EP}$ & [161] \\
\hline D. mellitae (Rathbun, 1900) & Echinoidea & 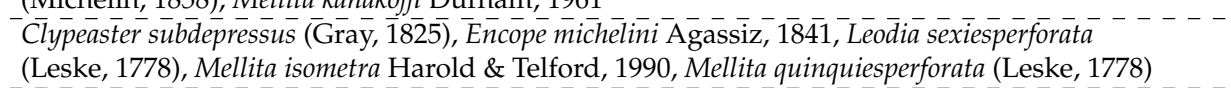 & ATL & {$[161]$} \\
\hline D. nitidus Smith, 1870 & Echinoidea & $\begin{array}{l}\text { Encope grandis Āgassiz, } \overline{1} \overline{84} \overline{1}, \bar{E} \text { ncope micropora californica Verrill, } 18 \overline{7} 0, \bar{E} \text { Ecope spp., } \\
\text { Lanthonia longifissa (Michelin, 1858) }\end{array}$ & $\begin{array}{l}--- \\
\mathrm{EP}\end{array}$ & {$[161]$} \\
\hline 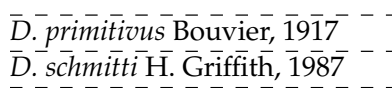 & 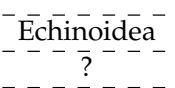 & 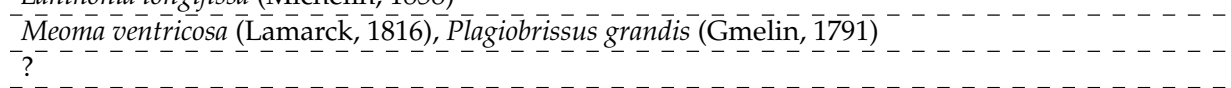 & $\begin{array}{l}\overline{\mathrm{A}} \overline{\mathrm{T}} \mathrm{L}^{-} \\
\overline{\mathrm{E}} \overline{\mathrm{P}}-\end{array}$ & $-\overline{[1} \overline{6} 1]$ \\
\hline D. xantusi Glassell, 1936 & Echinoidea & $\begin{array}{l}\text { Clypeaster subdepressus (Gray, } 18 \overline{2} 5), \bar{E} \text { Eope grandis Agassiz, } 18 \overline{1} 1, \text { Encope micropora californica } \\
\text { Verrill, 1870, Encope michellini Agassiz, 1841, Encope spp., Leodia sexiesperforata (Leske, 1778), } \\
\text { Mellitella stokesii (Agassiz, 1841), Lanthonia longifissa (Michelin, 1858) }\end{array}$ & EP & [161] \\
\hline \multicolumn{5}{|l|}{ Durckheimia } \\
\hline D. caeca Bürger, 1895 & Bivalvia & Chama pacifica Broderip, 1835, Lima lima (Linnaeus, 1758), Lima vulgaris (Link, 1807) & IWP & [27] \\
\hline D. carnipes De Man, $\overline{1} 8 \overline{8} 9^{-}-$ & $--\frac{-}{?}--$ & ? & $\overline{\mathrm{I}} \overline{\mathrm{W}} \overline{\mathrm{P}}$ & {$[27]^{-}$} \\
\hline D. lochi Âhyong \& Brown, 2003 & $\overline{\text { Bivàlvià }}$ & Ctenoides ales, Lima ve $\overline{\text { ulgaris }} \overline{(\mathrm{Lin}} \overline{\mathrm{k}}, \overline{1} \overline{80} \overline{7})^{-}$ & $\overline{\mathrm{I}} \overline{\mathrm{W}} \mathrm{P}$ & {$[27]^{-}$} \\
\hline \multicolumn{5}{|l|}{ Enigmatheres } \\
\hline E. canfieldi (Rathbun, 1918) & Gastropoda & Megathura crenulata (Sowerby, 1825) & EP & [61] \\
\hline \multicolumn{5}{|l|}{ Ernestotheres } \\
\hline E. conicola Manning, 1993 & Gastropoda & Conus sp. & ATL & [7] \\
\hline
\end{tabular}


Table 1. Cont.

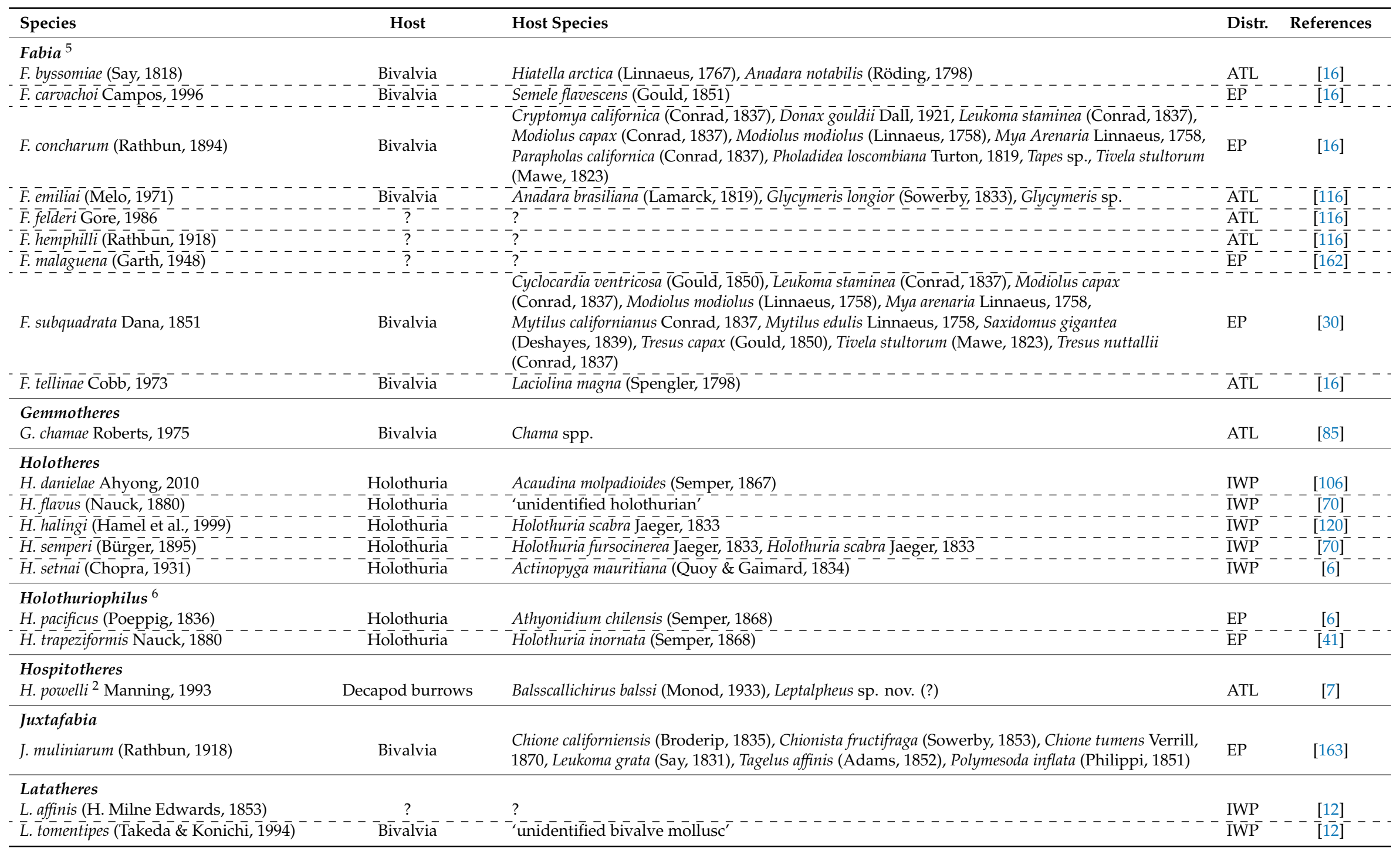


Table 1. Cont.

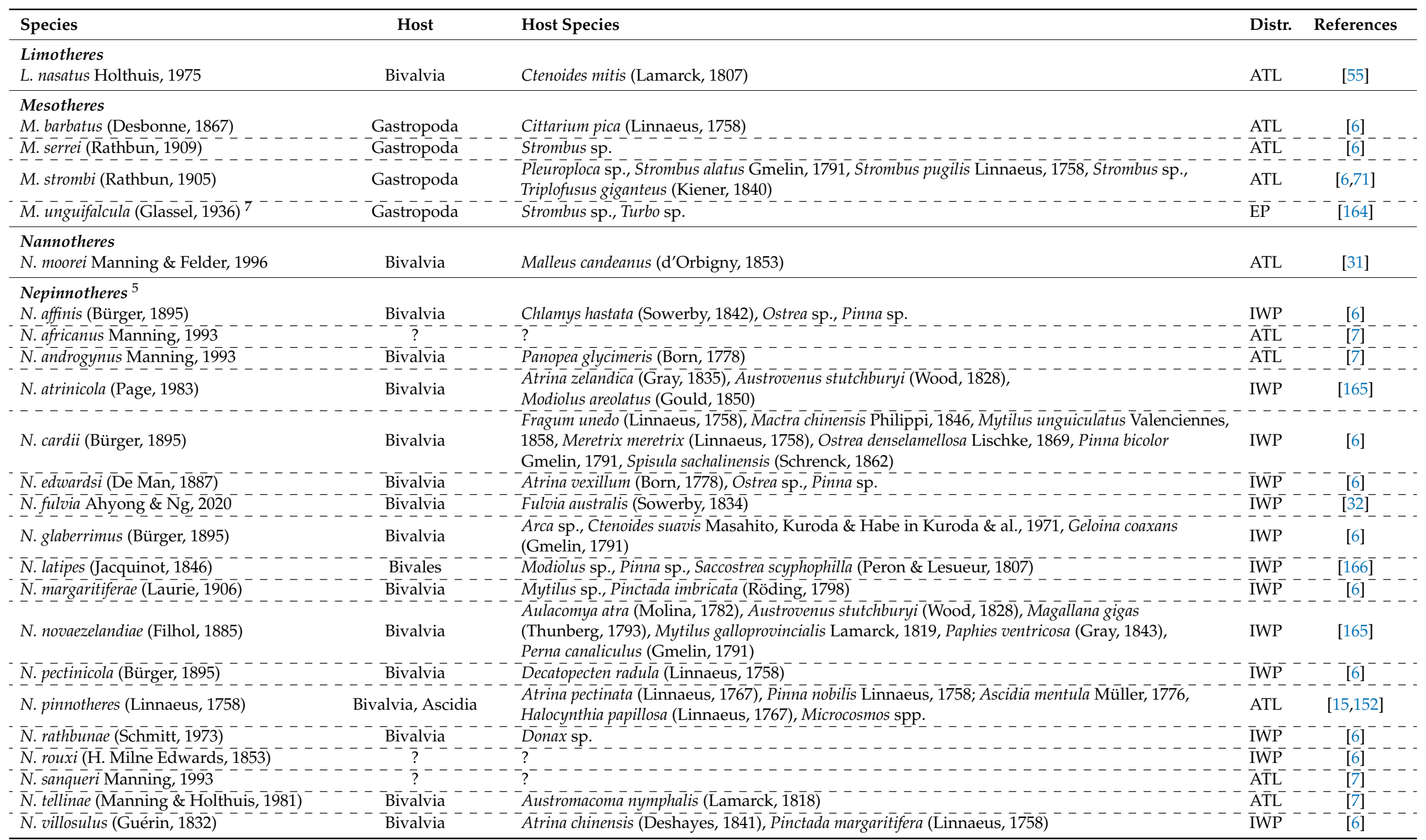


Table 1. Cont.

\begin{tabular}{|c|c|c|c|c|}
\hline Species & Host & Host Species & Distr. & References \\
\hline \multicolumn{5}{|l|}{ Opisthopus } \\
\hline O. transversus Rathbun, $1894^{8}$ & $\begin{array}{l}\text { Polyplacophora, } \\
\text { Gastropoda, Bivalvia, } \\
\text { Polychaeta, Holothuria }\end{array}$ & $\begin{array}{l}\text { Cryptochiton stelleri (Middendorff, 1847); Aplysia vaccaria Winkler, 1955, Bulla gouldiana Pilsbry, } \\
\text { 1895, Megastraea undosa (Wood, 1828), Megathura crenulata (Sowerby, 1825), Navanax inermis } \\
\text { (Cooper, 1862), Neverita lewisii (Gould, 1847); Crassadoma gigantea (Gray, 1825), Dinocardium } \\
\text { robustum (Lightfoot, 1768), Megapitaria squalida (Sowerby, 1835), Modiolus sp., Mytilus edulis } \\
\text { Linnaeus, 1758, Nuttallia nuttalli (Conrad, 1837), Pholas sp., Platyodon sp., Tivela stultorum } \\
\text { (Mawe, 1823), Tresus nuttallii (Conrad, 1837), Zirfaea pilsbryi Lowe, 1931, Zirfaea sp.; Arenicola sp., } \\
\text { Chaetopterus variopedatus (Renier, 1804); Apostichopus californicus (Stimpson, 1857), } \\
\text { Apostichopus parvimensis (Clark, 1913), Caudina sp. }\end{array}$ & EP & {$[6,30]$} \\
\hline \multicolumn{5}{|l|}{ Orthotheres } \\
\hline O. bayou $\mathrm{Ng} \& \mathrm{Ho}, 2016$ & Gastropoda & Haliotis asinine Linnaeus, 1758 & IWP & [112] \\
\hline O. haliotidis Geiger \& Martin, $1 \overline{999}{ }^{-}$ & Gastropōa & Haliotis asinina $\overline{\text { Linnaeus, }} \overline{1} \overline{1758}$ & $\overline{\mathrm{I}} \overline{\mathrm{W}} \mathrm{P}$ & {$[1 \overline{1} 2]$} \\
\hline O. tur $\bar{b}$ é T. Sakai, $\overline{1} 9 \overline{6} 9^{-\ldots-\ldots}$ & Gastropoda & Turbo argyrostomus Linnaeus, $\overline{1} 7 \overline{5} 8$ & $\overline{\mathrm{I}} \overline{\mathrm{W}} \mathrm{P}$ & {$[1 \overline{1} 2]$} \\
\hline \multicolumn{5}{|l|}{ Ostracotheres } \\
\hline O. cynthiae Nobili, 1906 & Ascidia & Herdmania momus (Savigny, 1816), Herdmania sp. & IWP & [12] \\
\hline O. tridacnae (Rüppel, 1830$)$ & Bivāivià & 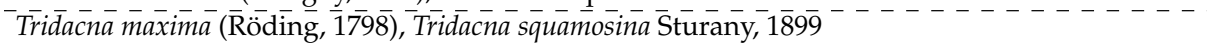 & $\overline{\mathrm{I}} \overline{\mathrm{W}} \mathrm{P}$ & {$[12]$} \\
\hline \multicolumn{5}{|l|}{ Pinnaxodes ${ }^{6}$} \\
\hline P. bipunctatus (Nicolet, 1849) & Echinoidea & 'probably sea-urchins' & EP & [167] \\
\hline P. chilensis (H. Milne Edwards, 1837) & Echinoidea & 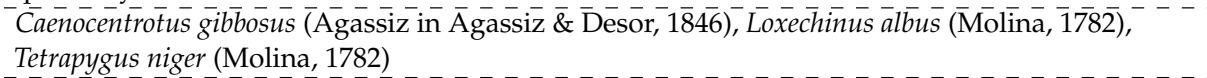 & EP & [167] \\
\hline 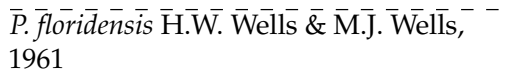 & Holothuria & Holothuria princeps Selenka, 1867 & ATL & [6] \\
\hline $\bar{P}$ P. & $-{ }_{-}^{-}$Bīvālviā - & 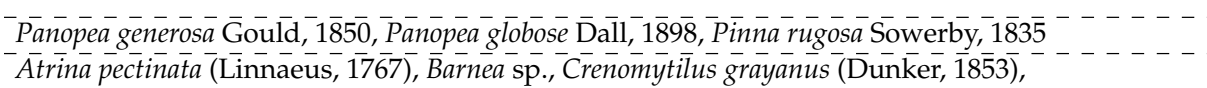 & $\bar{E}_{-}^{-}$ & $-\overline{3}]_{-}^{-}$ \\
\hline P. major Ortmann, 1894 & Bivalvia, Holothuria & $\begin{array}{l}\text { Gregariella difficilis (Deshayes, 1863), Mactra antiquata Spengler, 1802, Meretrix lamarckii Deshayes, } \\
\text { 1853, Mytilus sp., Ruditapes philippinarum (Adams \& Reeve, 1850); Holothuria hilla Lesson, 1830, } \\
\text { Stichopus gyrifer Selenka, 1867 }\end{array}$ & IWP & {$[6,87,168]$} \\
\hline \multirow{2}{*}{ P. mutuensis T. Sakai, 1939} & & 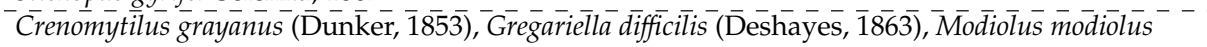 & & \\
\hline & Bivalvia & $\begin{array}{l}\text { (Linnaeus, 1758), Mya arenenaria Linnaeus, 1758, Mytilus edulis Linnaeus, } 1758, \\
\text { Mytilus galloprovincialis Lamarck, 1819, Mytilus unguiculatus Valenciennes, } 1858\end{array}$ & IWP & {$[70,168]$} \\
\hline 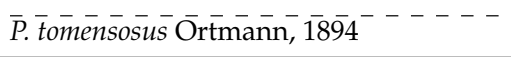 & $--\overline{\text { Bivalvià }}$ & 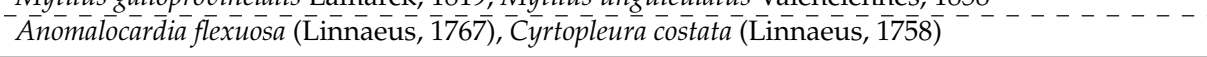 & $\overline{\mathrm{A}} \overline{\mathrm{T}} \mathrm{L}^{-}$ & $\overline{[} 1 \overline{6} 9 \overline{]}$ \\
\hline \multicolumn{5}{|l|}{ Pinnotheres ${ }^{5}$} \\
\hline P. bicristatus García Raso \& Cuesta, 2019 & Bivalvia & Anomia ephippium Linnaeus, 1758, Ostrea edulis Linnaeus, 1758 & ATL & ] \\
\hline 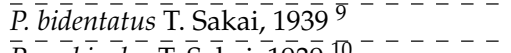 & 'Free living- & $?$ & $\overline{\mathrm{I}} \overline{\mathrm{V}} \overline{\mathrm{P}}$ & $-\overline{1} 1 \overline{1} 0]$ \\
\hline 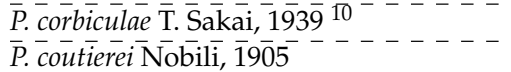 & $--\frac{\text { Bivalvia }}{?}--$ & & & $-{ }^{-}[\overline{6}]^{-}$ \\
\hline
\end{tabular}


Table 1. Cont.

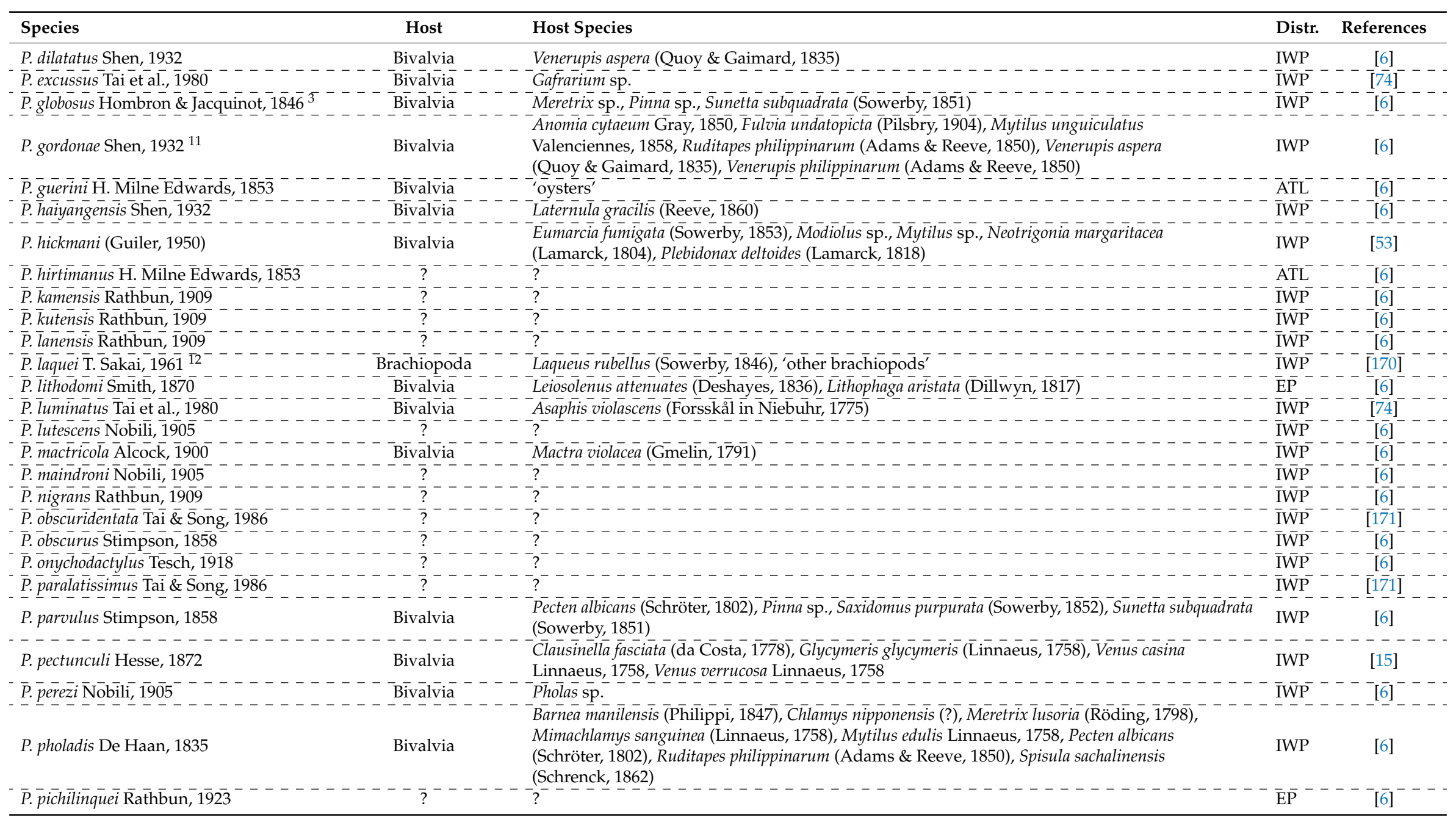


Table 1. Cont.

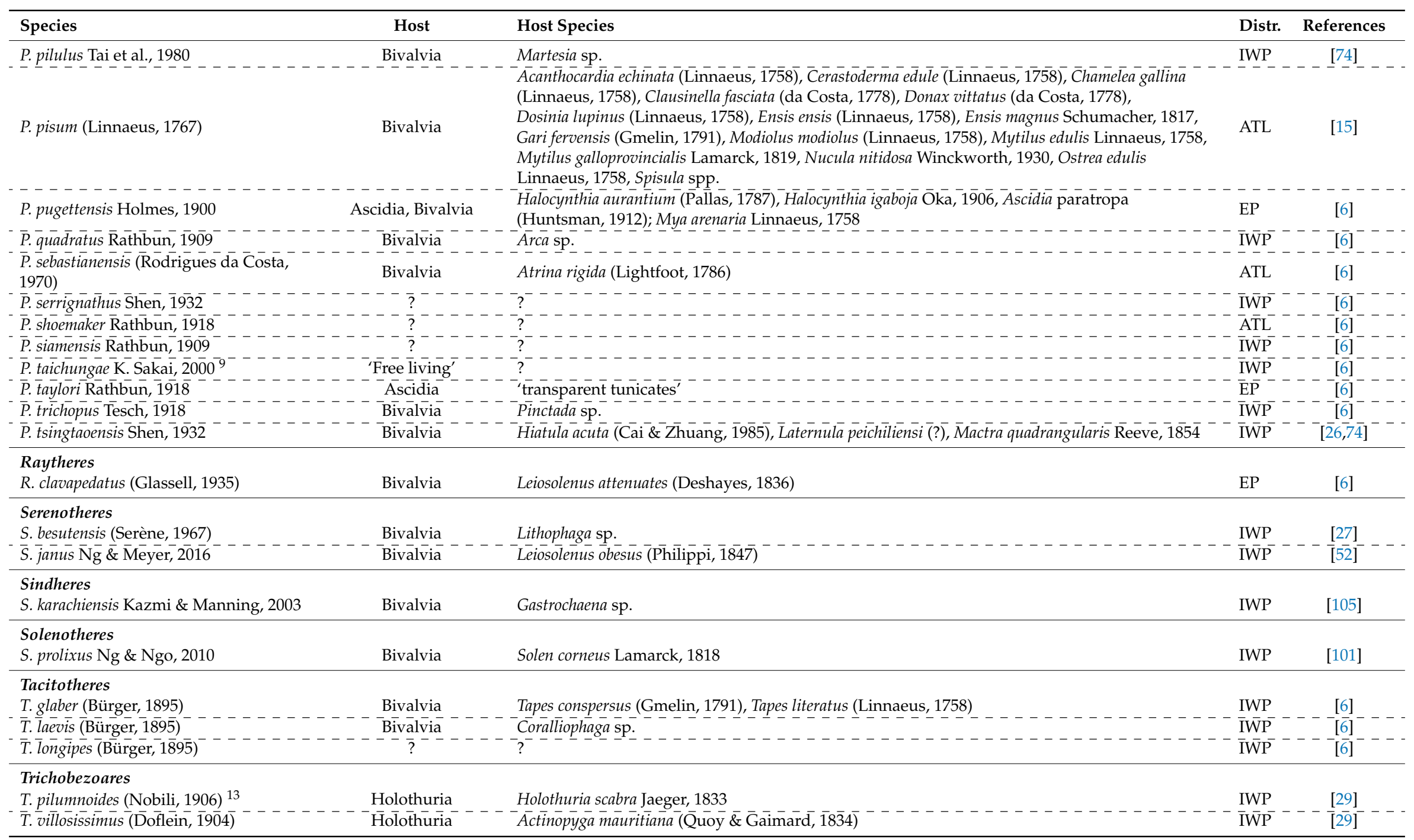


Table 1. Cont.

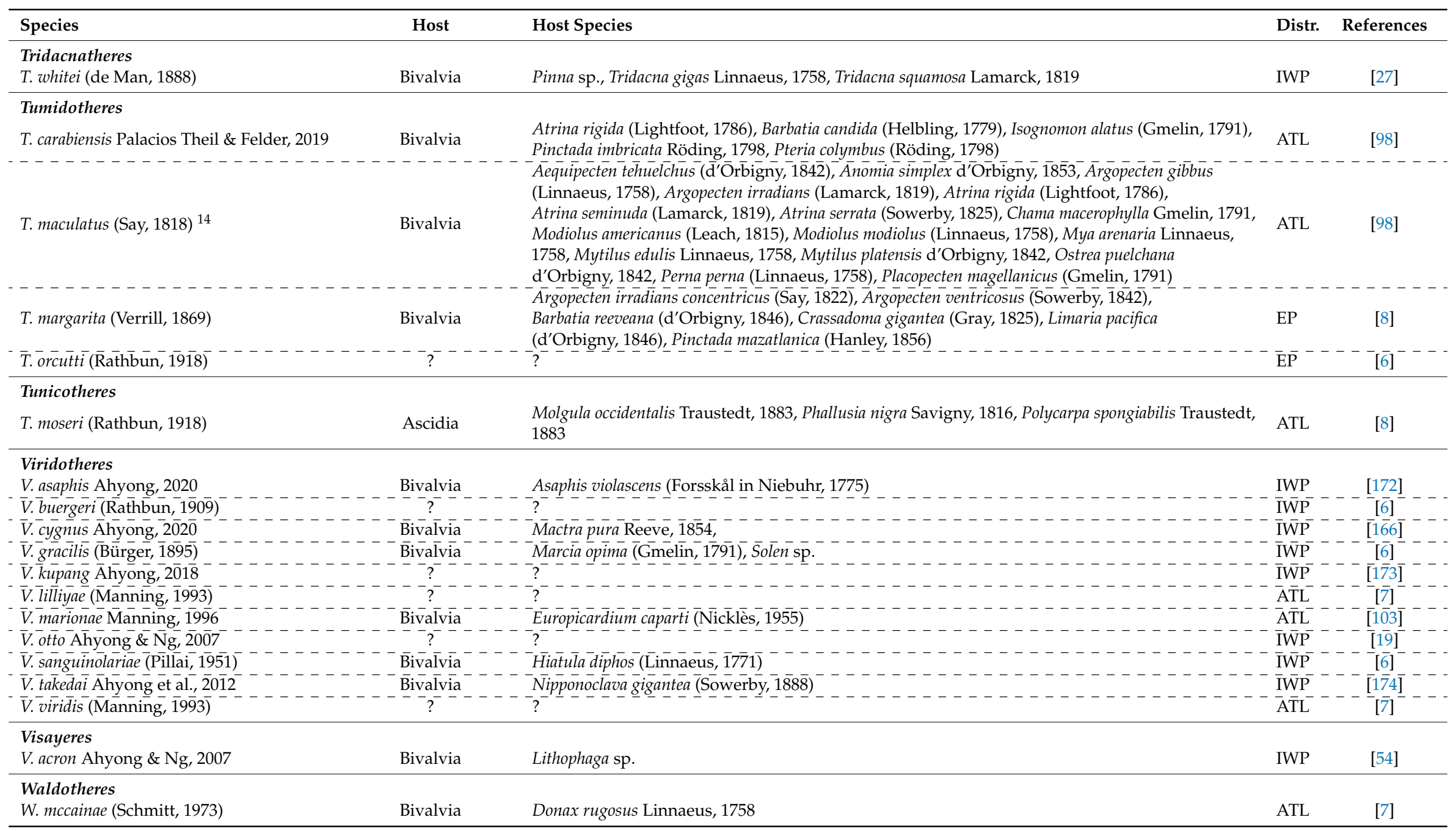


Table 1. Cont

\begin{tabular}{|c|c|c|c|c|}
\hline Species & Host & Host Species & Distr. & References \\
\hline \multicolumn{5}{|l|}{ Xanthasia } \\
\hline X. murigera White, 1846 & Bivalvia & $\begin{array}{l}\text { Hippopus sp., Tridacna crocea Lamarck, 1819, Tridacna gigas (Linnaeus, 1758), Tridacna maxima } \\
\text { (Röding, 1798), Tridacna squamosa Lamarck, } 1819\end{array}$ & IWP & [27] \\
\hline \multicolumn{5}{|l|}{ Zaops } \\
\hline Z. angelae Manning, 1993 & Bivalvia & Brachidontes modiolus (Linnaeus, 1767) & ATL & [98] \\
\hline Z. geddesi (Miers, 1880) & Bivalvia & Crassostrea rhizophorae (Guilding, 1828) & ATL & [6] \\
\hline Z. ostreum (Say, 1817) & Bivalvia & $\begin{array}{l}\text { Anomia peruviana d'Orbigny, 1846, Crassostrea rhizophorae (Guilding, 1828), Crassostrea virginica } \\
\text { (Gmelin, 1791), Mytilus edulis Linnaeus, } 1758 \text {, Pecten spp. }\end{array}$ & ATL & [6] \\
\hline
\end{tabular}

1: Ng and Kumar [91] showed Afropinnotheres to be present in the Indian Ocean, with the description of A. ratnakara, but most other species of Afropinnotheres are from the west coast of Africa, with A. monodi even reaching as far as Europe [152]. Afropinnotheres dofleini was described from South Africa, connecting the two distribution patterns [91]. ${ }^{2}$ : All twelve specimens listed in the original description of Hospitotheres powelli were found in the soft-soiled estuary in Bonny River (Nigeria), found in decapod burrows [7]. The specimens supposedly shared these burrows with Leptalpheus sp. nov. and Balsscallichirus balssi (as Callianassa balssi). The actual host of this species might be a bivalve (Galeommatoidea, Myidae and Lucinidae), living inside the same burrows as the decapods [175]. Consequently, the hypothetical host might have been destroyed during collection. Crabs identified as $H$. powelli appear to share many features with mollusk-inhabiting pea crabs, but closer inspection is needed. Another West African species, Alainotheres leloeuffi, shares a similar description of the habitat and was described based on one male specimen from a sandy sublittoral habitat in Ivory Coast. The only description of the habitat from the male holotype lacks information about a potential host, but mentioned it was dredged from "the reddish-brown sea floor (depth: $20 \mathrm{~m}$ )". Dredging is known to destroy delicate invertebrates, including the shells of bivalves, and might have dislodged the crab from its original host [176]. Another possibility is that the male crab had left its host to search for host-infesting females. ${ }^{3}$ : The holotype of the first described species from Singapore, Pinnotheres globosum Hombron \& Jacquinot, 1846 is considered lost, and the designation of a neotype will be published in 2020 (following [177]). Arcotheres latus (Bürger, 1895) and A. ridgewwayi (Southwell, 1911) were found to be synonymous with P. globosum (now probably in Arcotheres) [177]. Until a revision is published, we list all three species separately. ${ }^{4}$ : Although Dissodactylus meyerabichi is regarded a junior synonym of D. nitidus, some databases still include the species as an accepted name [3,4]. Following Griffith [93], we do not include this species in Table 1. Dissodactylus may also include six additional species described as Dissodactylus zoea stages from Japan [178]. Schmitt et al. [6] listed the six species as 'Species incertae', provisionally in a separate genus, Dissodactylozoea. The identity of these specimens remains unknown. ${ }^{5}$ : Although Fabia, Nepinnotheres, and Pinnotheres have been the subject of many revisions, erecting new genera accounting for previously included species [16,88,179], the three genera still prove to be polyphyletic [5]. The molecular phylogeny reconstruction of Palacios Theil et al. [5] included two species of Fabia and Nepinnotheres, all being placed in different lineages. Additional molecular and morphological studies are needed to properly revise the two genera, but the distribution of the members of Fabia and Nepinnotheres can provide hints of a more natural classification. Within Fabia, four species are from the eastern Pacific (including the type species F. subquadrata) and five are from the tropical Western Atlantic (including the other analysed species). Within Nepinnotheres, five species are from the Atlantic coast of Africa (with N. pinnotheres' also reaching Europe), while the remaining thirteen species can be found in the (greater) Pacific region, from India to New Zealand and the Philippines. Although Palacios Theil et al. [5] include only one species of Pinnotheres in their phylogenetic analyses, the genus is (still) urgently in need of a thorough revision, as stated by previous authors $[7,113,180]$. Evidence for the heterogeneity of the genus is the extreme morphological variation in the currently 45 recognised species, in addition to the absence of illustrations, host-information, and collection materials. A quick review of the illustrations of some of the better-known Indo-West Pacific species suggest already four species needing to be included in Arcotheres due to their sword-like dactyli on the last ambulatory legs: P. obscuridentata [171], P. excussus [74], and P. parvulus [156]. 
Proper examination is needed to refer the four (and possibly more) species to Arcotheres (as in [32,121]). ${ }^{6}$ : There are some unanswered questions about the taxonomy of Holothuriophilus and Pinnaxodes, most recently highlighted by Ng and Kumar [91]. Holothuriophilus pacificus and H. trapeziformis are listed as the only species within Holothuriophilus [3,4], but previous authors [87,169] mentioned Pinnaxodes mutuensis and P. tomentosus to also be included in Holothuriophilus (see [65]). Jiang and Liu [181], Marin [168], and subsequently Ng and Kumar [91] include the two species in Pinnaxodes, based on morphological differences between the two genera (see [70]). We follow Ng and Kumar [91] in including the two species in Pinnaxodes After Ng and Manning suggested it [70], Palacios Theil et al. [5] showed the southeastern Pacific species Holothuriophilus pacificus and Pinnaxodes chilensis to be related. The molecular phylogeny did not include the Indo-West Pacific and Western Atlantic species of Pinnaxodes, which are needed to solve this taxonomic problem. While both species of Holothuriophilus live in holothurians in the southeastern Pacific, members of Pinnaxodes have been found in a wide range of hosts organisms, from the Western Atlantic, Indo-West Pacific, and eastern Pacific Pinnaxodes chilensis can be found inside the rectums of several species of urchins [87,167], while P. bipunctatus was described "probably from a sea urchin" and has not been examined since [167]. Campos [167] placed the species in Pinnaxodes after detailed examination of the description, and suggested it is related to P. chilensis. Pinnaxodes floridensis can be found in western Atlantic waters, inside the respiratory system of holothurians [87]. This species was described by Wells and Wells [90] after examination of 174 specimens, and found to "live commensally, not harming the [holothurian] host". Although the Western Atlantic distribution raises questions about the generic status of this species, Takeda and Masahito [87] relate the species to the western Pacific P. major. Pinnaxodes major was reported as an inhabitant of a holothurian [182], which would be in line with the hosts of the other species of Pinnaxodes and Holothuriophilus. This species, however, can also be found in a wide range of shallow-water mussels and fan shells [87], as in P. mutuensis and P. tomentosus. In contrast, P. gigas, a species more recently described by Green [183] from the northeast Pacific has been found only once in fan shells [30]. Preferred hosts are geoduck clams. The host choice and potential switching (from a holothurian host to a geoduck within one life cycle) are discussed by Campos [30]. ${ }^{7}$ : Mesotheres unguifalcula can be found on the Pacific coasts of Mexico, in the stomachs of large gastropods from the genera Strombus and Turbo. Campos [164] mentioned the discovery of M. unguifalcula: "According to Glassell [184] the host for this species was not determined, but he recorded for the female topotypes that were collected "on the ambulacral groove of starfish." I consider that this needs confirmation." [164]. No other specimen has been collected from sea stars after 1936, so this might be an oddity or a rare encounter of an intermediate host. ${ }^{8}$ : Opisthopus transversus can be found in a wide range of hosts [185]: inside the folds and openings of chitons, gastropods, bivalves, and holothurians. Campos et al. [185] suggested the crab to also live inside annelid worms like Chaetopterus variopedatus, which contrasts with the lifestyle of the above mentioned Hospitotheres and most pinnixine genera. Schmitt et al. [6] mentioned the species as living as a commensal symbiont inside the tubes of living C. variopedatus, and cite Hopkins and Scanland [69]. Hopkins and Scanland [69] described the hosts of O. transversus and stated that they found the largest specimens inside large species of gastropods and bivalves, somewhat smaller specimens inside holothurians and the smallest specimens inside the small gastropod Bulla, and inside worm tubes of living C. variopedatus. Hopkins and Scanland [69] suggested that the juvenile crabs to seek shelter until they can compete with the other crabs inhabiting the worm tubes (here Pinnixa barnharti and Polynyx sp. (Porcellanidae)). In failing to do so, the crabs will inhabit the available holothurians and gastropods. These observations might however suggest the worms to be an intermediate host for the crabs until they can move to their terminal host. In the absence of a particular obligate host choice of $O$. transversus is a derived or primitive character is not known as for now, but can be studied using molecular techniques [5]. 9: Pinnotheres taichungae was originally identified as Pinnotheres bidentatus [110], an ambiguous species from two localities in Japan [186]. The specimens described by T. Sakai (both sexes) and later by K. Sakai (only males) as P. bidentatus have been regarded as free-living $[156,186]$. Similarly, P. taichungae is also known as a free-living species: "Female crabs of this species may not necessary behaving as its congeners - commensal in bivalves, they may emerge into water columns during flooding tides, presumably, buried to substrata during ebb tides, since the water margin retreats up to $3 \mathrm{~km}$ on the shoreline at this time." (about P. taichungae, as P. bidentatus, [110]). As McDermott [11] already stated, free living pinnotherines have probably been dislodged from their host in the collection procedure The swimming setae on all ambulatory legs described by Hsueh and Huang [110] suggest the specimens to be hard staged males and females, maybe leaving their hosts for copulation [10]. ${ }^{10}$ : Pinnotheres corbiculae can only be found in the brackish-water clam Corbicula japonica, which makes it the only pinnotherid crab living in a brackish environment. T. Sakai [156] 
described the species from 'Yamato-sizimi' clams (C. japonica), from the southern Sendai river (Kagoshima prefecture, Japan), and mentions another uncertain locality from Nagasaki. He mentioned the species to be the only pinnotherid living inside freshwater clams, but recent studies suggest $C$. japonica only to be found in brackish water in Japan and Korea where populations cannot live for long durations in environments with salinity greater than $21 \mathrm{psu}$ or less than $0.3 \mathrm{psu}$ [187]. Pinnotheres corbiculae has not been collected after the original description and appears to only be present in southern Japan. More specimens are needed find if $P$. corbiculae can be found in $C$. japonica in other parts of Japan, if water salinity is related to infestation rate, and if the species has evolved morphological adaptations to live in brackish environments. ${ }^{11}$ : Pinnotheres gordoni was found by Ng et al. [3] to represent the female of Pinnotheres gordonae. ${ }^{12}$ : The unique host-choice of this crab was described by T. Sakai in 1961 (see [182]). Not baring any morphological adaptations, Pinnotheres laquei can be found in a common Japanese brachiopod, Laqueus rubellus, and supposedly in more species of brachiopods [170]. Although the external morphology of this brachiopod resembles bivalves, the internal morphology is unique to the group. Feldmann et al. [170] described the positioning and commensal lifestyle of $P$. laquei in its host, and mentions this species to be the only $\mathrm{crab}$ (and one of a few invertebrates) to live in association with a brachiopod. ${ }^{13}$ : While the original description by Nobili [188] of Trichobezoares pilumnoides did not mention any hosts, Laurie [189] two female specimens from holothurians and one female specimen from a sponge [29]. Laurie's observation is probably a rare finding of a soft-shelled female leaving the holothurian host. There is an additional (new) species that is found in sponges from the Caribbean [68], but the sex of this species is undetermined and this might also be just a male crab wandering between hosts. ${ }^{14}$ : Tumidotheres maculatus can be found in a wide range of bivalve hosts, but also in the tubes of worms and sometimes free-living in sandy substrates [6]. All other species of Tumidotheres are only found in bivalves, and since T. maculatus is found to be closely related to its congeners [5,98], it is safe to say that the free-living and specimens of this species inhabiting worm tubes were collected during a swarming event, as described by Derby and Atema [10] and Campos [8]. We therefore chose to only list the bivalve associates. 


\section{Phylogenetic Significance of Adaptive Features and Future Perspectives}

The phylogenetic significance of the morphological adaptations can be examined by linking the adaptations with recent molecular phylogenetic reconstructions [5,18]. Most adaptive features seem to be the result of convergent evolution, rather than shared synapomorphies [5], and these are: the size, ornamentations, colour patterns, and setation of the carapace, in addition to the differences between male and female carapaces; the morphology of the eyes, rostrum, third maxillipeds [85], and the specialised feeding structures on the chelipeds. More data are needed to confirm if the adaptive features of the ambulatory legs bear any phylogenetic significance (especially the features of the dactyli).

Although many more species need to be included in future molecular analyses, a few adaptive features could be phylogenetically relevant characters that are taxonomically important. The development of swimming setae in both males and females in their hard stages for copulation in open water (the 'second strategy' in [8]) can be found in some genera listed within the West Atlantic and eastern Pacific 'Pinnotherinae II' group (sensu [5]). The swimming setae can be found in Calyptraeotheres, Fabia (specifically F. subquadrata), and Tumidotheres, and may be used by Fabia emiliai (de Melo, 1971) and Juxtafabia muliniarum (Rathbun, 1918), judging from the swimming setae seen in the presented figures $[116,163]$. This strategy is not known from the other species clustering in the same lineage: Tunicotheres moseri, Holothuriophilus pacificus (Poeppig, 1836), Pinnaxodes chilensis, and the species in the Dissodactylus complex.

All these species have a firm to hard carapace in the 'post-hard' stages of the female, which is not the case in the other analysed branches of pinnotherine evolution and might be an adaptation associated with open-water copulation. Such 'swarming' behaviour is also known from some Austrotheres species, and female swimming setae are known from some members of Afropinnotheres, Nepinnotheres, Ostracotheres, and Pinnotheres (all not included in the phylogenetic reconstructions [5]). Those are all species from the Indo-West Pacific and will probably be placed elsewhere on the tree later on.

Another character was found in all branches of the 'Pinnotherinae II' [5]: the relatively large and robust chelae present in all species within the Dissodactylus complex (all members within Dissodactylus and Clypeasterohilus), all species of Tunicotheres, Tumidotheres, Holothuriophilus, Pinnaxodes, Calyptraeotheres, and Fabia subquadrata, F. emiliai, and Juxtafabia muliniarum. Although the feeding strategies and the use of chelae might differ between species (e.g., strictly parasitic feeding on host tissues in Dissodactylus using their chelae, 'grooming' in Fabia using the setal comb, and filter feeding in Pinnaxodes using the third maxillipeds), the chelae are very different from the feeble chelipeds of other crabs included in the phylogenetic reconstruction [5] like the Vietnamese bivalve-associated Solenotheres prolixus Ng \& Ngo, 2010, the Chinese/Thai Amusiotheres obtusidentatus (Tai et al., 1980), and the European Pinnotheres pisum.

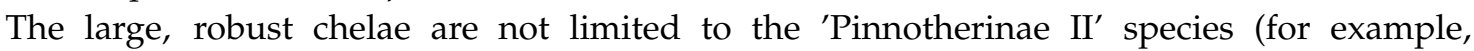
Nepinnotheres pinnotheres, and Alain raymondi Ahyong \& Ng, 2008 also possess relatively large chelae), and one species with slender chelae, Zaops ostreum, might be more closely related to Tumidotheres than previously thought [98] and might cluster within the 'Pinnotherinae II'.

Although most recent evolutionary studies on pea crabs have been focussing on a small subgroup of the Pinnotherinae [98], or the other pinnotherid subfamilies [18], the study by Palacios Theil et al. [5] provides a sufficiently large base for further studies on the complete pinnotherine evolution. Genetic barcodes of more species, especially those from the Indo-West Pacific, are needed to solve taxonomic problems, but also to build a complete and robust phylogeny.

A large-scale revision of Indo-West Pacific pinnotherids will be published in the near future [49]. Using a combination of phylogenetic reconstructions with morphometric analyses and detailed host information, detailed insights regarding patterns of convergent evolution and adaptive radiation of morphological structures can be obtained. such studies will constitute a crucial contribution to our understanding of pinnotherid biodiversity. 
Supplementary Materials: The following are available online at http://www.mdpi.com/1424-2818/12/11/431/s1, A video of the rotating 3D models of the CT-scanned material from Figures 1 and 3 can be found in the supplementary data.

Author Contributions: Conceptualization, W.d.G. and C.B.; methodology, W.d.G. and C.B.; investigation, W.d.G.; data curation, W.d.G.; writing-original draft preparation, W.d.G.; writing-review \& editing, W.d.G. and C.B.; visualization, W.d.G. and C.B. All authors have read and agreed to the published version of the manuscript.

Funding: The authors received no external funding.

Acknowledgments: The authors would like to thank Bert W. Hoeksema (Naturalis Biodiversity Center and University of Groningen) for his general feedback and for his assistance during the last stages of writing. Charles H. J. M. Fransen, Ronald Vonk (both Naturalis Biodiversity Center), Stephen K. Donovan, and Jeroen Hubert (Leiden University) are thanked for their helpful comments and feedback. The authors would like to show gratitude to Dirk van der Marel and Rob Langelaan for their assistance operating the CT-scanners in the imaging facilities of Naturalis Biodiversity Center. Marco Faasse (Naturalis Biodiversity Center and Coast Marine Research, Marlin Harms (via Flickr), Ang Yuchen and Jonathan Ho (Lee Kong Chian Natural History Museum) are thanked for their help by providing pictures for Figure 4. In addition, the authors would like to thank Peter K. L. Ng (Lee Kong Chian Natural History Museum) for providing information and literature on a few obscure pea crab species, and three anonymous reviewers for their insightful comments.

Conflicts of Interest: The authors declare no conflict of interests.

\section{References}

1. Baeza, J.A. Crustaceans as symbionts: An overview of their diversity, host use, and lifestyles. In Lifestyles and Feeding Biology -The Natural History of the Crustacea; Thiel, M., Watling, L., Eds.; Oxford University Press: Oxford, UK, 2015; Volume 2, pp. 163-189.

2. Castro, P. Symbiotic Brachyura. In Treatise on Zoology—Anatomy, Taxonomy, Biology, The Crustacea; Part C-I-Decapoda: Brachyura (Part-1); Castro, P., Davie, P.J.F., Guinot, D., Schram, F.P., von Vaupel Klein, J.C., Eds.; Brill: Leiden, The Netherlands, 2015; Volume 9, pp. 543-581.

3. Ng, P.K.L.; Guinot, D.; Davie, P.J.F. Systema Brachyurorum: Part I. An annotated checklist of extant Brachyuran crabs of the world. Raffles Bull. Zool. 2008, 17, 1-286.

4. WoRMS: World Register of Marine Species. Available online: https://www.marinespecies.org (accessed on 22 June 2020).

5. Palacios Theil, E.; Cuesta, J.A.; Felder, D.L. Molecular evidence for non-monophyly of the pinnotheroid crabs (Crustacea: Brachyura: Pinnotheroidea), warranting taxonomic reappraisal. Invertebr. Syst. 2016, 30, 1-27. [CrossRef]

6. Schmitt, W.L.; McCain, J.C.; Davidson, E.S. Crustaceorum Catalogus: Decapoda I-Brachyura I-Fam. Pinnotheridae; Dr. W. Junk B.V.: Den Haag, The Netherlands, 1973; pp. 1-160.

7. Manning, R.B. West African pinnotherid crabs, subfamily Pinnotherinae (Crustacea, Decapoda, Brachyura). Bull. Mus. Natl. D'histoire Nat. Paris Ser. 1993, 15, 125-177.

8. Campos, E. Tumidotheres, a new genus for (Pinnotheres margarita) Smith, 1869, and Pinnotheres maculatus Say, 1818 (Brachyura: Pinnotheridae). J. Crustacean Biol. 1989, 9, 672-679. [CrossRef]

9. Ocampo, E.H.; Spivak, E.D.; Baeza, J.A.; Luppi, T.A. Ontogenetic changes in the external anatomy of the parasitic castrator crab Calyptraeotheres garthi: Implications for the timing of host colonization and sexual behaviour. Biol. J. Linn. Soc. 2017, 120, 54-74.

10. Derby, C.D.; Atema, J. Induced host odor attraction in the pea crab Pinnotheres maculatus. Biol. Bull. 1980, 158, 26-33. [CrossRef]

11. McDermott, J.J. Hypersymbioses in the pinnotherid crabs (Decapoda: Brachyura: Pinnotheridae): A review. J. Nat. Hist. 2009, 43, 785-805. [CrossRef]

12. Ahyong, S.T. Revision of Ostracotheres H. Milne Edwards, 1853 (Crustacea: Brachyura: Pinnotheridae). Raffles Bull. Zool. 2018, 66, 538-571.

13. Werding, B.; Sanchez, H. Pinnotherid crabs of the genus Dissodactylus Smith, 1870, associated with irregular sea urchins at the Caribbean coast of Colombia (Crustacea: Decapoda: Pinnotheridae). Zool. Meded. 1989, $63,35-42$.

14. Serène, R. A note on the systematics of the Brachyura and the morphology of commensal species. Proc. Ninth Pac. Sci. Congr. 1961, 10, 32-33. 
15. Becker, C.; Türkay, M. Host specificity and feeding in European pea crabs (Brachyura: Pinnotheridae). Crustaceana 2017, 90, 819-844. [CrossRef]

16. Campos, E. Partial revision of the genus Fabia Dana, 1851 (Crustacea: Brachyura: Pinnotheridae). J. Nat. Hist. 1996, 30, 1157-1178. [CrossRef]

17. Watanabe, T.; Henmi, Y. Morphological development of the commensal pea crab (Arcotheres sp.) in the laboratory reared specimens. J. Crustacean Biol. 2009, 29, 217-223. [CrossRef]

18. Palacios Theil, E.; Felder, D.L. Phylogeny of the genus Austinixa Heard \& Manning, 1997, inferred from mitochondrial and nuclear molecular markers, with descriptions of three new species and redescription of Austinixa felipensis (Glassell, 1935) (Decapoda: Brachyura: Pinnotheridae). Zootaxa 2020, 4778, 101-134. [CrossRef]

19. Ahyong, S.T.; Ng, P.K.L. The pinnotherid type material of Semper (1880), Nauck (1880) and Bürger (1895) (Crustacea: Decapoda: Brachyura). Raffles Bull. Zool. Suppl. 2007, 191-226.

20. Rathbun, M.J. The Grapsoid Crabs of America. Bull. U. S. Natl. Mus. 1918, 97, 1-461. [CrossRef]

21. FEI Avizo @9.5.0 User Manual; Konrad-Zuse-Zentrum für Informationstechnik Berlin (ZIB): Berlin, Germany, 2018.

22. Baeza, J.A.; Thiel, M. The mating system of symbiotic crustaceans: A conceptual model based on optimality and ecological constraints. In Evolutionary Ecology of Social and Sexual Systems: Crustaceans as Model Organisms; Duffy, J.E., Thiel, M., Eds.; Oxford University Press: Oxford, UK, 2007; pp. 250-267.

23. Christensen, A.M.; McDermott, J.J. Life-history and biology of the oyster crab, Pinnotheres ostreum Say. Biol. Bull. 1958, 114, 146-179. [CrossRef]

24. Yanagisawa, Y.; Hamaishi, A. Mate acquisition by a solitary crab Zebrida adamsii, a symbiont of the sea urchin. J. Ethol. 1986, 4, 153-162. [CrossRef]

25. Alves, F.D.R.; Hirose, G.L.; Barros-Alves, S.D.P.; Baeza, J.A. The mating system of the symbiotic pea-crab Dissodactylus crinitichelis (Brachyura, Pinnotheridae): Monogamy or promiscuity? Mar. Biol. 2017, 164, 200. [CrossRef]

26. Soong, K. Some life history observations on the pea crab, Pinnotheres tsingtaoensis, symbiotic with the bivalve mollusk, Sanguinolaria acuta. Crustaceana 1997, 70, 855-866. [CrossRef]

27. Ahyong, S.T.; Ng, P.K.L. Review of Durckheimia and Xanthasia, with descriptions of two new genera (Decapoda: Brachyura: Pinnotheridae). J. Crustacean Biol. 2005, 25, 116-129. [CrossRef]

28. Ahyong, S.T.; Ng, P.K.L. Alain raymondi, a new species of deepwater pinnotherid crab (Crustacea: Decapoda: Brachyura) from the Philippines, commensal with holothurians. Zootaxa 2008, 1919, 61-68. [CrossRef]

29. Ng, P.K.L. On the identities of Pinnotheres villosissimus Doflein, 1904, P. dofleini Lenz, in Lenz \& Strunck, 1914, and P. pilumnoides Nobili, 1906 (Decapoda, Brachyura, Pinnotheridae) from the Western Indian Ocean. Crustaceana 2018, 91, 611-633. [CrossRef]

30. Campos, E. The Pinnotheridae of the northeastern Pacific (Alaska to Mexico): Zoogeographical remarks and new bivalve hosts (Crustacea, Brachyura, Pinnotheridae). Zootaxa 2016, 4170, 311-329. [CrossRef]

31. Manning, R.B.; Felder, D.L. Nannotheres moorei, a new genus and species of minute pinnotherid crab from Belize, Caribbean Sea (Crustacea: Decapoda: Pinnotheridae). Proc. Biol. Soc. Wash. 1996, 109, 311-317.

32. Ahyong, S.T.; Ng, P.K.L. New species of pinnotherid crabs from Southeast Asia and Papua New Guinea (Crustacea: Decapoda: Brachyura). Zootaxa 2020, 4816, 333-349. [CrossRef]

33. Cuesta, J.A.; Raso, J.E.G.; Abelló, P.; Marco-Herrero, E.; Silva, L.; Drake, P. A new species of pea crab from south-western Europe (Crustacea, Decapoda, Brachyura): Species description, geographic distribution and population structure with an identification key to European Pinnotheridae. J. Mar. Biol. Assoc. UK 2019, 99, 1141-1152. [CrossRef]

34. Hines, A.H. Constraint on reproductive output in brachyuran crabs: Pinnotherids test the rule. Am. Zool. 1992, 32, 503-511. [CrossRef]

35. Haines, C.M.C.; Edmunds, M.; Pewsey, A.R. The pea crab, Pinnotheres pisum (Linnaeus 1767), and its association with the common mussel, Mytilus edulis (Linnaeus, 1758), in the Solent (U.K.). J. Shellfish Res. 1994, 13, 5-10.

36. Hsueh, P.W. Responses of the pea crab Pinnotheres taichungae to the life history patterns of its primary bivalve host Laternula marilina. J. Nat. Hist. 2003, 37, 1453-1462. [CrossRef]

37. Marco-Herrero, E.; Galimany, E.; Abelló, P.; Cuesta, J.A.; Drake, P.; Ramón, M. Updating hosts and distribution range of the pea crab Pinnotheres bicristatus (Brachyura: Pinnotheridae). Mediterr. Mar. Sci. 2020, 21, 499-505. [CrossRef] 
38. Drake, P.; Marco-herrero, E.; Subida, M.D.; Arias, A.M.; Cuesta, J.A. Host use pattern of the pea crab Afropinnotheres monodi: Potential effects on its reproductive success and geographical expansion. Mar. Ecol. Prog. 2014, 498, 203-215. [CrossRef]

39. Sun, W.; Sun, S.; Yuqi, W.; Baowen, Y.; Weibo, S. The prevalence of the pea crab, Pinnotheres sinensis, and its impact on the condition of the cultured mussel, Mytilus galloprovincialis, in Jiaonan waters (Shandong Province, China). Aquaculture 2006, 253, 57-63. [CrossRef]

40. Salas-Moya, C.; Mena, S.; Wehrtmann, I.S. Reproductive traits of the symbiotic pea crab Austinotheres angelicus (Crustacea, Pinnotheridae) living in Saccostrea palmula (Bivalvia, Ostreidae), Pacific coast of Costa Rica. ZooKeys 2014, 457, 239-252. [CrossRef] [PubMed]

41. Ocampo, E.H.; Nuñez, J.D.; Cledón, M.; Baeza, J.A. Host specific reproductive benefits, host selection behavior and host use pattern of the pinnotherid crab Calyptraeotheres garthi. J. Exp. Mar. Biol. Ecol. 2012, 429, 36-46. [CrossRef]

42. Atkins, D. The moulting stages of the pea-crab (Pinnotheres pisum). J. Mar. Biol. Assoc. 1926, 14, 475-484. [CrossRef]

43. Becker, C.; Türkay, M. Taxonomy and morphology of European pea crabs (Crustacea: Brachyura: Pinnotheridae). J. Nat. Hist. 2010, 44, 1555-1575. [CrossRef]

44. Hoeksema, B.W. Het erwtenkrabbetje Pinnotheres pisum (L.), als commensaal van de paardemossel Modiolus modiolus (L.). Zeepaard 1981, 41, 79.

45. Pearce, J.B. The Biology of the mussel crab, Fabia subquadrata, from the Waters of the San Juan Archipelago, Washington. Pac. Sci. 1966, 20, 3-35.

46. Takahashi, T.; Otani, T.; Matsuura, S. Swimming behaviour of the pinnotherid, crab, Tritodynamia horvathi observed during the low temperature season. J. Mar. Biol. Assoc. UK 1999, 79, 375-377. [CrossRef]

47. De Bruyn, C. Modalités Fonctionnelles et Évolutives des Parasitoses Développées par les Crabes Pinnotheridae aux Dépens des Échinides Fouisseurs. Ph.D. Thesis, Universite de Bourgogne, Bourgogne, France, 2010.

48. Pohle, G.; Telford, M. Post-larval growth of Dissodactylus primitivus Bouvier, 1917 (Brachyura: Pinnotheridae) under Laboratory Conditions. Biol. Bull. 1982, 163, 211-224. [CrossRef]

49. Komai, T.; Kei, K.; Ng, P.K.L. On the identity of the poorly known pea crab, Pinnothera obesa Dana, 1852, and description of a new species of Arcotheres Manning, 1993 from the Southwest Pacific (Decapoda: Brachyura: Pinnotheridae). Zootaxa 2020, 4822, 221-247. [CrossRef] [PubMed]

50. Zmarzly, D.L. Taxonomic review of pea crabs in the genus Pinnixa (Decapoda: Brachyura: Pinnotheridae) occurring on the California Shelf, with descriptions of two new species. J. Crustacean Biol. 1992, 12, 677-713. [CrossRef]

51. Manning, R.B.; Felder, D.L. The Pinnixa cristata complex in the Western Atlantic, with descriptions of two new species (Crustacea: Decapoda: Pinnotheridae). Smithson. Contrib. Zool. 1989, 473, 1-26. [CrossRef]

52. Ng, P.K.L.; Meyer, C. A new species of pea crab of the genus Serenotheres Ahyong \& Ng, 2005 (Crustacea, Brachyura, Pinnotheridae) from the date mussel Leiosolenus Carpenter, 1857 (Mollusca, Bivalvia, Mytilidae, Lithophaginae) from the Solomon Islands. ZooKeys 2016, 623, 31-41. [CrossRef]

53. Ahyong, S.T.; Brown, D.E. Description of Durckheimia lochi n. sp., with an annotated check-list of Australian Pinnotheridae (Crustacea: Decapoda: Brachyura). Zootaxa 2003, 254, 1-20. [CrossRef]

54. Ahyong, S.T.; Ng, P.K.L. Visayeres acron, a new genus and species of pinnotherid crab (Crustacea: Decapoda: Brachyura) from the Philippines. Raffles Bull. Zool. Suppl. 2007, 16, 187-189.

55. Holthuis, L.B. Limotheres, a new genus of pinnotherid crab, commensal of the bivalve Lima, from the Caribbean Sea. Zool. Meded. 1975, 48, 291-295.

56. Guinot, D.; Wicksten, M.K. Camouflage: Carrying behaviour, decoration behaviour, and other modalities of concealmens in Brachyura. In Treatise on Zoology-Anatomy, Taxonomy, Biology, The Crustacea; Part C-I-Decapoda: Brachyura (Part-1); Castro, P., Davie, P.J.F., Guinot, D., Schram, F.P., von Vaupel Klein, J.C., Eds.; Brill: Leiden, The Netherlands, 2015; Volume 9, pp. 583-638.

57. Fransen, C.H.J.M. Shrimps and Molluscs/Garnalen en Weekdieren. Vita Mar. 1994, 42, 105-113.

58. Fransen, C.H.J.M. Taxonomy, phylogeny, historical biogeography, and historical ecology of the genus Pontonia Latreille (Crustacea: Decapoda: Caridea: Palaemonidae). Zool. Verh. 2002, 336, 1-433. [CrossRef]

59. Mebs, D. Chemical biology of the mutualistic relationships of sea anemones with fish and crustaceans. Toxicon 2009, 54, 1071-1074. [CrossRef] [PubMed] 
60. Komatsu, H.; Ohtsuka, S. A new species of the genus Abyssotheres (Crustacea, Decapoda, Brachyura, Pinnotheridae) from the Ryukyu Islands, Southwestern Japan, with taxonomic notes on the genus. Bull. Natl. Mus. Nat. Sci. Ser. A Zool. 2009, 35, 73-81.

61. Campos, E. A new species and two new genera of pinnotherid crabs from the northeastern Pacific Ocean, with a reappraisal of the subfamily Pinnotherinae de Haan, 1833 (Crustacea: Brachyura: Pinnotheridae). Zootaxa 2009, 2022, 29-44. [CrossRef]

62. Humann, P.; Deloach, N. Reef Creature Identification: Tropical Pacific, 1st ed.; New World Publications, Inc.: Jacksonville, FL, USA, 2017; pp. 1-497.

63. Caro, T. The functional significance of coloration in crabs. Biol. J. Linn. Soc. 2018, 124, 1-10. [CrossRef]

64. Marine Biodiversity Survey of St. Eustatius, Dutch Caribbean, 2015-Preliminary Results of the Statia Marine Biodiversity Expedition, 2015; Hoeksema, B.W. (Ed.) Naturalis Biodiversity Center, Leiden, and ANEMOON Foundation: Bennebroek, The Netherlands, 2016; pp. 1-157.

65. Campos, E.; Peláez-zárate, V.A.; Solís-marín, F.A. Rediscovery, hosts and systematics of Holothuriophilus trapeziformis Nauck, 1880 (Crustacea, Brachyura, Pinnotheridae). Zootaxa 2012, 3528, 57-62. [CrossRef]

66. Atkins, D. On nocturnal colour change in the pea-crab (Pinnotheres veterum). Nature 1926, 117, 415-416. [CrossRef]

67. De Bruyn, C.; David, B.; Motreuil, S.; Caulier, G.; Jossart, Q.; Rigaud, T.; De Ridder, C. Should I stay or should I go? Causes and dynamics of host desertion by a parasitic crab living on echinoids. Mar. Ecol. Prog. Ser. 2016, 546, 163-171. [CrossRef]

68. Humann, P.; Deloach, N.; Wilk, L. Reef Creature Identification: Florida, Caribbean, Bahamas, 3rd ed.; New World Publications, Inc.: Jacksonville, FL, USA, 2013; pp. 1-295.

69. Hopkins, T.S.; Scanland, T.B. The host relations of a pinnotherid crab, Opisthopus transversus Rathbun (Crustacea: Decapoda). Bull. South. Calif. Acad. Sci. 1964, 63, 175-180.

70. Ng, P.K.L.; Manning, R.B. On two new genera of pea crabs parasitic in holothurians (Crustacea: Decapoda: Brachyura: Pinnotheridae) from the Indo-West Pacific, with notes on allied genera. Proc. Biol. Soc. Wash. 2003, 116, 901-919.

71. Ng, P.K.L.; Ahyong, S.T.; Campos, E. Two new genera of pinnotherid crabs (Crustacea: Brachyura: Pinnotheroidea) from the Americas and the Western Pacific. Raffles Bull. Zool. 2019, 67, 337-351. [CrossRef]

72. Miers, E.J. The Voyage of H.M.S. Challenger-Report of the Brachyura collected by H.M.S. Challenger during the years 1873-76. In Report on the Scientific Results of the Voyage of H.M.S.; Eyre \& Spottiswoode: London, UK, 1886; pp. 1-362.

73. De Man, J.G. Report on the podophthalmous Crustacea of the Mergui Archipelago, collected for the Trustees of the Indian Museum, Calcutta, by Dr. John Anderson-Part II. J. Linn. Soc. 1887, 22, 65-128. [CrossRef]

74. Tai, A.; Yang, S. Crabs of the China Seas; China Ocean Press: Beijing, China; Springer: Berlin, Germany, 1991; pp. 421-437.

75. Kruczynski, W.L. Relationship between depth and occurrence of pea crabs, Pinnotheres maculatus, in blue mussels, Mytilus edulis, in the Vicinity of Woods Hole, Massachusetts. Chesap. Sci. 1974, 15, 167-169. [CrossRef]

76. Wass, M.L. A new pinnixid commensal with a holothurian (Crustacea: Decapoda). Tulane Stud. Zool. 1968, 14, 137-139. [CrossRef]

77. Luckenbach, M.W.; Orth, R.J. A chemical defense in Crustacea? J. Exp. Mar. Biol. Ecol. 1990, 137, 79-87. [CrossRef]

78. Jossart, Q.; Terrana, L.; De Ridder, C.; Eeckhaut, I.; Monteyne, D.; Caulier, G. To see or to smell: The role of vision in host-recognition by an ectoparasitic crab. Symbiosis 2020, 80, 97-101. [CrossRef]

79. De Bruyn, C.; David, B.; De Ridder, C.; Rigaud, T. Asymmetric exploitation of two echinoid host species by a parasitic pea crab and its consequences for the parasitic life cycle. Mar. Ecol. Prog. Ser. 2010, 398, 183-191. [CrossRef]

80. Dobson, N.C.; De Grave, S.; Johnson, M.L. Linking eye design with host symbiont relationships in pontoniine shrimps (Crustacea, Decapoda, Palaemonidae). PLoS ONE 2014, 9, e99505. [CrossRef]

81. Dobson, N.C.; Johnson, M.L.; De Grave, S. Insights into the morphology of symbiotic shrimp eyes (Crustacea, Decapoda, Palaemonidae); the effects of habitat demands. Peer] 2016, 4, e1926. [CrossRef]

82. Souza, J.; Barroso, D.; Hirose, G.L. Chemical recognition in the symbiotic pea crab Dissodactylus crinitichelis (Crustacea: Decapoda: Pinnotheridae): Host and conspecific cues. J. Exp. Mar. Biol. Ecol. 2018, 511, 108-112. [CrossRef] 
83. Davie, P.J.F.; Guinot, D.; Ng, P.K.L. Anatomy and functional morphology of Brachyura. In Treatise on Zoology-Anatomy, Taxonomy, Biology, The Crustacea; Part C-Decapoda: Brachyura (Part-1); Castro, P., Davie, P.J.F., Guinot, D., Schram, F.P., von Vaupel Klein, J.C., Eds.; Brill: Leiden, The Netherlands, 2015; Volume 9, pp. 11-163.

84. Campos, E. Two new genera of pinnotherid crabs from the tropical Eastern Pacific (Decapoda: Brachyura: Pinnotheridae). J. Crustacean Biol. 2002, 22, 328-336. [CrossRef]

85. Campos, E.; Hernández-Aguilera, J.L. First record and range extension of the Jewel Box clam crab Gemmotheres chamae (Roberts, 1975) to the Gulf of Mexico, with comments on the systematics of the pinnotherines with a 2-segmented palp on the third maxilliped (Crustacea: Brachyura: Pinnotherida. Naupl. -J. Braz. Crustacean Soc. 2020, 28, 1-7. [CrossRef]

86. Ahyong, S.T.; Ng, P.K.L. Aphanodactylidae, a new family of thoracotreme crabs (Crustacea: Brachyura) symbiotic with polychaete worms. Zootaxa 2009, 2289, 33-47. [CrossRef]

87. Takeda, M.; Masahito, P. Systematic notes on the pinnotherid crabs of the genus Pinnaxodes (Crustacea: Decapoda: Brachyura). Bull. Natl. Sci. Mus. Tokyo 2000, 26, 99-112.

88. Campos, E. Partial revision of pinnotherid crab genera with a two-segmented palp on the third maxilliped (Decapoda: Brachyura). J. Crustacean Biol. 1996, 16, 556-563. [CrossRef]

89. Campos, E. Calyptraeotheres, a new genus of Pinnotheridae for the limpet crab Fabia granti Glassell, 1933 (Crustacea, Brachyura). Proc. Biol. Soc. Wash. 1990, 103, 364-371.

90. Wells, H.W.; Wells, M.J. Observations on Pinnaxodes floridensis, a new species of pinnotherid crustacean commensal in holothurians. Bull. Mar. Sci. Gulf Caribb. 1961, 11, 267-279.

91. Ng, P.K.L.; Kumar, A.B. A new species of Afropinnotheres Manning, 1993 (Crustacea, Brachyura, Pinnotheridae) from southwestern India, the first record of the genus from the Indian Ocean, with a review of the Pinnotheridae of India and adjacent seas. Zootaxa 2015, 3947, 264-274. [CrossRef] [PubMed]

92. Griffith, H. Phylogenetic relationships and evolution in the genus Dissodactylus Smith, 1870 (Crustacea: Brachyura: Pinnotheridae). Can. J. Zool. 1987, 65, 2292-2310. [CrossRef]

93. Griffith, H. Taxonomy of the genus Dissodactylus (Crustacea: Brachyura: Pinnotheridae) with descriptions of three new species. Bull. Mar. Sci. 1987, 40,397-422.

94. Pohle, G. Structure, function, and development of setae on gill-grooming appendages and associated mouthparts of pinnotherid crabs (Decapoda: Brachyura). Can. J. Zool. 1989, 67, 1690-1707. [CrossRef]

95. Pohle, G.; Marques, F. Phylogeny of the Pinnotheridae: Larval and adult evidence, with emphasis on Phylogeny of the Pinnotheridae: Larval and adult evidence, with emphasis on the evolution of gills. Invertebr. Reprod. Dev. 1998, 33, 229-239. [CrossRef]

96. Vader, W. Associations between amphipods (Crustacea: Amphipoda) and sea anemones (Anthozoa: Actiniaria). Aust. Mus. Mem. 1983, 18, 141-153. [CrossRef]

97. Telford, M. Echinoderm spine structure, feeding and host relationships of four species of Dissodactylus (Brachyura: Pinnotheridae). Bull. Mar. Sci. 1982, 32, 584-594.

98. Palacios Theil, E.; Felder, D.L. Molecular phylogeography of Tumidotheres maculatus (Say, 1818) and Zaops ostreus (Say, 1817) (Crustacea: Decapoda: Pinnotheridae) in the western Atlantic, with description of a new species and synonymy of Epulotheres Manning, 1993. Mar. Biol. Res. 2019, 15, 548-567. [CrossRef]

99. Jones, S.; Mahadevan, S. Notes on animal associations. 5. The pea crab Pinnotheres deccanensis Chopra inside the respiratory tree of the sea cucumber, Holothuria scabra Jager. J. Mar. Biol. Assoc. India 1965, 7, 377-380.

100. Bell, J.L. Changing residence: Dynamics of the symbiotic relationship between Dissodactylus mellitae Rathbun (Pinnotheridae) and Mellita quinquiesperforata (Leske) (Echinodermata). J. Exp. Mar. Biol. Ecol. 1984, 82, 101-115. [CrossRef]

101. Ng, P.K.L.; Ngo, V.T. Solenotheres prolixus, a new genus and new species of pinnotherid crab (Crustacea: Decapoda: Brachyura) associated with the razor clam, Solen corneus Lamarck, 1818 (Solenidae) in Vietnam. Zootaxa 2010, 2570, 61-68. [CrossRef]

102. Ng, P.K.L.; Ho, P. A new genus for Fabia obtusidentata Dai, Feng, Song and Chen, 1980, a pea crab (Decapoda: Brachyura: Pinnotheridae) symbiotic with the moon scallop Amusium pleuronectes (Linnaeus, 1758) (Mollusca: Pectinidae). J. Crustacean Biol. 2016, 36, 740-751. [CrossRef]

103. Manning, R.B. Viridotheres marionae, a new genus and species of pinnotherid crab from West Africa (Crustacea: Decapoda: Brachyura). Zool. Meded. 1996, 70, 271-273. 
104. Campos, E.; Manning, R.B. The Identities of Pinnotheres nudus Holmes, 1895 and P. nudus sensu Weymouth, 1910 (Crustacea: Decapoda: Pinnotheridae). Proc. Biol. Soc. Wash. 2000, 113, 799-805.

105. Kazmi, Q.B.; Manning, R.B. A new genus and species of pinnotherid crab from Karachi, northern Arabian Sea (Crustacea, Decapoda, Brachyura). J. Nat. Hist. 2003, 37, 1085-1089. [CrossRef]

106. Ahyong, S.T. Holotheres danielae, a new species of pinnotherid crab from the Indo-West Pacific (Decapoda, Brachyura), with a key to the genus. Crustaceana Monogr. 2010, 11, 35-40.

107. Mesce, K.A. Morphological and physiological identification of chelar sensory structures in the hermit crab Pagurus hirsutiusculus (Decapoda). J. Crustacean Biol. 1993, 13, 95-110. [CrossRef]

108. Hartnoll, R.G. Swimming in the hard stage of the pea crab, Pinnotheres pisum (L.). J. Nat. Hist. 1972, 6, 475-480. [CrossRef]

109. Stauber, L.A. Pinnotheres ostreum, parasitic on the American oyster, Ostrea (Gryphaea) virginica. Biol. Bull. 1945, 88, 269-291. [CrossRef]

110. Hsueh, P.W.; Huang, J.F. A new record of Pinnotheres bidentatus Sakai, 1939 (Decapoda: Brachyura: Pinnotheridae), from Taiwan. Crustacean Res. 1996, 25, 54-58. [CrossRef]

111. Atkins, D. British pea-crabs (Pinnotheres). Nature 1958, 4615, 1087. [CrossRef]

112. Ng, P.K.L.; Ho, P. Orthotheres baoyu, a new species of pea crab (Crustacea: Brachyura: Pinnotheridae) associated with abalones from Tungsha Island, Taiwan; with notes on the genus. Raffles Bull. Zool. 2016, 64, 229-241.

113. Gordon, I. On a few Indo-Pacific species of Pinnotheres, with special reference to asymmetry of the walking legs. J. Linn. Soc. Lond. Zool. 1936, 40, 163-180. [CrossRef]

114. Griffin, D.J.G.; Campbell, B.M. The sub-littoral Goneplacidae and Pinnotheridae (Crustacea: Brachyura) of Moreton Bay. Mem. Qld. Mus. 1969, 15, 141-163.

115. Campos, E. A new crab species of the genus Arcotheres Manning, 1993, from Thailand (Crustacea, Brachyura, Pinnotheridae). Zoosystema 2001, 23, 493-497.

116. Campos, E. Remarks on the sexual dimorphism and taxonomy of Fabia Dana, 1851 (Crustacea, Brachyura, Pinnotheridae). Zootaxa 2013, 3616, 190-200. [CrossRef] [PubMed]

117. Campos, E.; Manning, R.B. Authorship and diagnosis of the genus Arcotheres Manning, 1993 (Crustacea: Brachyura: Pinnotheridae). Raffles Bull. Zool. 2001, 49, 167-170.

118. Campos, E.; Griffith, H. Clypeasterophilus, a new genus to receive the small-palped species of the Dissodactylus complex (Brachyura: Pinnotheridae). J. Crustacean Biol. 1990, 10, 550-553. [CrossRef]

119. Manning, R.B.; Galil, B. A new genus of pinnotherid crab from the Indian Ocean (Crustacea: Decapoda: Brachyura). Proc. Biol. Soc. Wash. 2000, 113, 66-69.

120. Hamel, J.; Ng, P.K.L.; Mercier, A. Life cycle of the pea crab Pinnotheres halingi sp. nov., an obligate symbiont of the sea cucumber Holothuria scabra Jaeger. Ophelia 1999, 50, 149-175. [CrossRef]

121. Ng, P.K.L.; Clark, P.F.; Mitra, S.; Kumar, A.B. Arcotheres borradailei (Nobili, 1906) and Pinnotheres ridgewayi Southwell, 1911: A reassessment of characters and generic assignment of species to Arcotheres Manning, 1993 (Decapoda, Brachyura, Pinnotheridae). Crustaceana 2017, 90, 1079-1097. [CrossRef]

122. Trivedi, J.N.; Vachhrajani, K.D.; Ng, P.K.L. Redescription of Arcotheres placunae (Hornell \& Southwell, 1909) (Crustacea: Decapoda: Brachyura: Pinnotheridae) from India and Pakistan. Zootaxa 2018, 4433, 50-58.

123. Trivedi, J.N.; Gosavi, S.; Vachhrajani, K.D.; Mitra, S.; Ravinesh, R.; Ng, P.K.L. On the identities of Nepinnotheres vicajii (Chhapgar, 1957) and Arcotheres casta (Antony \& Kuttyamma, 1971) from western India: Conspecificity and taxonomy (Decapoda, Brachyura, Pinnotheridae). Zootaxa 2020, 4809, 496-508.

124. De Gier, W.; Fransen, C.H.J.M. Odontonia plurellicola sp. n. and Odontonia bagginsi sp. n., two new ascidian-associated shrimp from Ternate and Tidore, Indonesia, with a phylogenetic reconstruction of the genus (Crustacea, Decapoda, Palaemonidae). Zookeys 2018, 765, 123-160. [CrossRef]

125. Campos, E. Inclusion of the austral species Pinnotheres politus (Smith, 1869) and Pinnotheres garthi Fenucci, 1975 within the genus Calyptraeotheres Campos, 1990 (Crustacea: Brachyura: Pinnotheridae). Proc. Biol. Soc. Wash. 1999, 112, 536-540.

126. Hernández-Ávila, I.; Campos, E. Calyptraeotheres hernandezi (Crustacea: Brachyura: Pinnotheridae), a new crab symbiont of the West Indian cup-and-saucer Crucibulum auricula (Gmelin) (Mollusca: Gastropoda: Calyptraeidae) off Cubagua Island, Venezuela. Proc. Biol. Soc. Wash. 2006, 119, 43-48. [CrossRef] 
127. Campos, E.; Hernández-ávila, I. Phylogeny of Calyptraeotheres Campos, 1990 (Crustacea, Decapoda, Brachyura, Pinnotheridae) with the description of C. pepeluisi new species from the tropical Mexican Pacific. Zootaxa 2010, 2691, 41-52. [CrossRef]

128. Ayón-parente, M.; Hendrickx, M.E. Calyptraeotheres sp. nov. (Crustacea: Decapoda: Pinnotheridae), symbiont of the slipper shell Crepidula striolata Menke, 1851 (Mollusca: Gastropoda: Calyptraeidae) from the Gulf of California, Mexico. Zootaxa 2014, 3872, 89-94. [CrossRef] [PubMed]

129. Hines, A.H. Fecundity and reproductive output in nine species of Cancer crabs (Crustacea, Brachyura, Cancridae). Can. J. Fish. Aquat. Sci. 1991, 48, 267-275. [CrossRef]

130. Hartnoll, R.G. Reproductive Investment in Brachyura. Hydrobiologica 2006, 557, 31-40. [CrossRef]

131. Telford, M. Distribution of two species of Dissodactylus (Brachyura Pinnotheridae) among their echinoid host populations in Barbados. Bull. Mar. Sci. 1978, 28, 651-658.

132. Becker, C. European Pea Crabs-Taxonomy, Morphology, and Host-Ecology (Crustacea: Brachyura: Pinnotheridae). Ph.D. Thesis, Universität in Frankfurt am Main, Frankfurt, Germany, 2010.

133. George, S.B.; Boone, S. The ectosymbiont crab Dissodactylus mellitae-Sand dollar Mellita isometra relationship. J. Exp. Mar. Biol. Ecol. 2003, 294, 235-255. [CrossRef]

134. McClay, C.L.; Becker, C. Reproduction in Brachyura. In Treatise on Zoology-Anatomy, Taxonomy, Biology, The Crustacea; Part C-I-Decapoda: Brachyura (Part-1); Castro, P., Davie, P.J.F., Guinot, D., Schram, F.P., von Vaupel'Klein, J.C., Eds.; Brill: Leiden, The Netherlands, 2015; Volume 9, pp. 185-243.

135. Becker, C.; Brandis, D.; Storch, V. Morphology of the female reproductive system of European pea crabs (Crustacea, Decapoda, Brachyura, Pinnotheridae). J. Morphol. 2011, 272, 12-26. [CrossRef]

136. Becker, C.; Klaus, S.; Tudge, C. Male internal reproductive structures of European pea crabs (Crustacea, Decapoda, Brachyura, Pinnotheridae): Vas deferens morphology and spermatozoal ultrastructure. J. Morphol. 2013, 274, 1312-1322. [CrossRef]

137. Vehof, J.; van der Meij, S.E.T.; Türkay, M.; Becker, C. Female reproductive morphology of coral-inhabiting gall crabs (Crustacea: Decapoda: Brachyura: Cryptochiridae). Acta Zool. 2016, 97, 117-126. [CrossRef]

138. de Souza, L.P.; Silva, J.R.F. Morfología del sistema reproductivo de las hembras del cangrejo rojo de mangle (Goniopsis cruentata Latreille, 1803). Sci. Mar. 2009, 73, 527-539. [CrossRef]

139. Cobo, V.J.; Fransozo, A. Physiological maturity and relationships of growth and reproduction in the red mangrove crab Goniopsis cruentata (Latreille) (Brachyura, Grapsidae) on the coast of São Paulo, Brazil. Rev. Bras. Zool. 2005, 22, 219-223. [CrossRef]

140. Strathmann, R.R.; Strathmann, M.F. The relationship between adult size and brooding in marine invertebrates. Am. Nat. 1982, 119, 91-101. [CrossRef]

141. Bush, A.O.; Fernández, J.C.; Esch, G.W.; Seed, J.R. Parasitism: The Diversity and Ecology of Animal Parasites; Cambridge University Press: Cambridge, UK, 2001; pp. 1-516.

142. Martin, J.W. 55: Brachyura. In Atlas of Crustacean Larvae; Martin, J.W., Olesen, J., Høeg, J.T., Eds.; Johns Hopkins University Press: Baltimore, ML, USA, 2014; pp. 1-384.

143. Gonzalez-Canales, M.E.; Marco-Herrero, E.; Andreu-Cazenave, M.; González-Gordillo, J.I. Larval development of the symbiotic pea crab Pinnaxodes chilensis (H. Milne Edwards, 1837) (Decapoda, Brachyura, Pinnotheridae) reared in laboratory. Arthropod Struct. Dev. 2018, 47, 91-103. [CrossRef] [PubMed]

144. Pohle, G. Larval development of Dissodactylus Rugatus Bouvier, 1917 (= D. Calmani Rathbun, 1918) (Brachyura: Pinnotheridae) reared under laboratory conditions. J. Crustacean Biol. 1984, 4, 572-588. [CrossRef]

145. Lebour, M.V. The Larval Stages of the Plymouth Brachyura. Proc. Zool. Soc. Lond. 1928, 98, 473-560. [CrossRef]

146. Marco-Herrero, E.; Drake, P.; González-Gordillo, J.I.; Cuesta, J.A. Larval development of the pea crab Afropinnotheres monodi Manning, 1993 (Decapoda, Pinnotheridae) using plankton-collected and laboratory-reared specimens: Effects of temperature. Mar. Biol. Res. 2016, 12, 43-55. [CrossRef]

147. Morgan, S.G. Morphological and behavioral antipredatory adaptations of decapod zoeae. Oecologia 1987, 73, 393-400. [CrossRef]

148. Goodbody, I. Abbreviated development in a pinnotherid crab. Nature 1960, 185, 704-705. [CrossRef]

149. Bolaños, J.; Rivero, W.; Hernández, J.; Magán, I.; Hernández, G.; Cuesta, J.A.; Felder, D.L. Abbreviated larval development of the pea crab Orthotheres barbatus (Decapoda: Brachyura: Pinnotheridae) described from laboratory-reared material, with notes on larval characters of the Pinnotherinae. J. Crustacean Biol. 2005, 25, 500-506. [CrossRef] 
150. Bolaños, J.; Cuesta, J.A.; Hernández, G.; Hernández, J.; Felder, D.L. Abbreviated larval development of Tunicotheres moseri (Rathbun, 1918) (Decapoda: Pinnotheridae), a rare case of parental care among brachyuran crabs*. Sci. Mar. 2004, 68, 373-384. [CrossRef]

151. Silas, E.G.; Alagarswami, K. On an instance of parasitisation by the pea-crab (Pinnotheres sp.) on the backwater clam [Meretrix casta (Chemnitz)] from India, with a review of the work on the systematics, ecology biology and ethology of pea crabs of the genus Pinnotheres Latreille*. In Proceedings of the Symposium on Crustacea, Ernakulam, India, 12-15 January 1965; Part III (Series 2). pp. 1161-1227.

152. Pérez-Miguel, M.; Drake, P.; Garcia Raso, J.E.; Mamám Menéndez, L.; Navas, J.I.; Cuesta, J.A. European Pinnotheridae (Crustacea, Decapoda, Brachyura): Species, distribution, host use and DNA barcodes. Mar. Biodivers. 2019, 49,57-68. [CrossRef]

153. Manning, R.B. A new genus and species of pinnotherid crab from Karachi, northern Arabian Sea (Crustacea, Decapoda, Brachyura). Zoosystema 1998, 20, 357-362. [CrossRef]

154. Devi, K.N.; Shyamasundari, K. A new species of Pinnotheres Latreille (Decapoda: Brachyura) from Visakhapatnam coast of Bay of Bengal, Andhra Pradesh. J. Bombay Nat. Hist. Soc. 1989, 86, 217-221.

155. Kazmi, Q.; Sultana, R.; Ghory, F. Redescription of Arcotheres placunae and three new records, A. aff. alcocki, A. casta and Pinnotheres quadratus from Pakistan with a note on previously recorded Pakistani Pinnotherid crabs. Pak. J. Mar. Sci. 2016, 25, 131-143.

156. Sakai, T. Studies on the Crabs of Japan IV; Yokendo: Tokyo, Japan, 1939; pp. 583-605.

157. Ng, P.K.L. Arcotheres placunicola, a new species of pea crab (Crustacea: Brachyura: Pinnotheridae) from the window-pane shell, Placuna ephippium Philipsson, 1788 (Placunidae) in Singapore. Raffles Bull. Zool. 2018, $66,474-485$.

158. Mohanty, B.; Raut, D.; Dev Roy, M.K.; Raman, A.V.; Patnaik, L.; Nayak, A.; Rout, S.S.; Dash, B. New host record of pea crab Arcotheres purpureus (Alcock, 1900) (Crustacea: Decapoda: Pinnotheridae) with first description of male. Mar. Biodivers. Rec. 2018, 11, 1. [CrossRef]

159. Kuo, A.-L.; Lin, F.-J.; Hsu, H.-T.; Chan, Y.-S.; Ueng, Y.-T. The population structure and parasitic relationships of oyster (Crassostrea angulata), Arcotheres sinensis (Pinnotheridae), and Rhopalione sinensis (Bopyridae) at the oyster reefs of Western Taiwan. Crustaceana 2018, 91, 1433-1451. [CrossRef]

160. Ribeiro, F.B.; Matthews-Cascon, H.; Bezerra, L.E.A. Record of the pea-crab Calyptraeotheres garthi (Fenucci, 1975) (Brachyura, Pinnotheridae) in Tropical Atlantic Ocean. Arq. Ciências Mar. 2020, 53, 143-148. [CrossRef]

161. Filho, J.E.M.; Brito dos Santos, R.; Ribeiro, C.C. Host selection, host-use pattern and competition in Dissodactylus crinitichelis and Clypeasterophilus stebbingi (Brachyura: Pinnotheridae). Symbiosis 2014, 63, 99-110. [CrossRef]

162. Campos, E.; Manning, R.B. Pinnotheres malaguena Garth, 1948, a new member of the genus Fabia Dana, 1851 (Crustacea: Brachyura: Pinnotheridae). Proc. Biol. Soc. Wash. 1998, 111, 912-915.

163. Campos, E. Systematics and taxonomic remarks on Pinnotheres muliniarium Rathbun, 1918 (Crustacea: Brachyura: Pinnotheridae). Proc. Biol. Soc. Wash. 1993, 106, 92-101.

164. Campos, E. Comments on taxonomy of the genus Orthotheres Sakai, 1969 (Crustacea, Brachyura, Pinnotheridae). Bull. Mar. Sci. 1989, 44, 1123-1128.

165. Page, R.D.M. Description of a new species of Pinnotheres, and redescription of P. novaezelandiae (Brachyura: Pinnotheridae). N. Z. J. Zool. 1983, 10, 151-162. [CrossRef]

166. Ahyong, S.T. Resolution of the identity of Pinnotheres latipes Hombron \& Jacquinot, 1846 and description of a new species of Viridotheres Manning, 1996 (Decapoda: Brachyura: Pinnotheridae): Two symbionts of bivalve molluscs. J. Crustacean Biol. 2020, 1-8. [CrossRef]

167. Campos, E. Taxonomy of Pinnotheres bipunctatus Nicolet, 1849 with a distributional checklist of the Pinnotheridae of Chile and Peru, and a list of the Crustacea described by Hercule Nicolet in the atlas of the physical and political history of Chile. Lat. Am. J. Aquat. Res. 2017, 45, 379-390. [CrossRef]

168. Marin, I.N. Finding of the pea crab Pinnaxodes mutuensis Sakai, 1939 (Crustacea: Decapoda: Pinnotheridae) in an unusual host in Busse Lagoon, southern Sakhalin. Russ. J. Mar. Biol. 2014, 40, 486-489. [CrossRef]

169. De Melo, G.A.S.; Boehs, G. Rediscovery of Holothuriophilus tomentosus (Ortmann) comb. nov. (Crustacea, Brachyura, Pinnotheridae) in the Brazilian coast. Rev. Bras. Zool. 2004, 21, 229-232. [CrossRef]

170. Feldmann, R.M.; Mackinnon, D.I.; Endo, K.; Chirino-Galvez, L. Pinnotheres laqueisakai (Decapoda: Pinnotheridae), a tiny crab commensal within the brachiopod Laqueus rubellus (Sowerby) (Terebratulida: Laqueidae). J. Paleontol. 1996, 70, 303-311. [CrossRef] 
171. Tai, A.; Song, W. Crabs of the China Seas; China Ocean Press: Beijing, China, 1991; pp. 54-62. (In Chinese)

172. Ahyong, S.T. Discovery of Viridotheres Manning, 1996 in the southwestern Pacific and first record of Discorsotheres camposi Ahyong, 2018 from New Caledonia (Crustacea: Brachyura: Pinnotheridae). Zootaxa 2020, 4763, 429-434. [CrossRef] [PubMed]

173. Ahyong, S.T. First Indonesian Viridotheres Manning, 1996, and redescription of male Afropinnotheres dofleini Manning, 1993, from South Africa (Decapoda, Pinnotheridae). Crustaceana 2019, 92, 107-118. [CrossRef]

174. Ahyong, S.T.; Komai, T.; Watanabe, T. First Viridotheres Manning, 1996, from Japan, with a key to the species (Decapoda, Brachyura, Pinnotheridae). In Studies on Eumalacostraca: A Homage to Masatsune Takeda; Komatsu, H., Okuno, J., Fukuoka, K., Eds.; Brill: Leiden, The Netherlands, 2012; pp. 35-48. [CrossRef]

175. Goto, R.; Ohsuga, K.; Kato, M. Mode of life of Anomiostrea coralliophila Habe, 1975 (Ostreidae): A symbiotic oyster living in ghost-shrimp burrows. J. Molluscan Stud. 2014, 80, 201-205. [CrossRef]

176. Števčić, Z.; Castro, P.; Gore, R.H. Re-establishment of the family Eumedonidae Dana, 1853 (Crustacea: Brachyura). J. Nat. Hist. 1988, 22, 1301-1324. [CrossRef]

177. Ng, P.K.L.; Corbari, L. Crustacea: Crab Legacies. In Voyageurs, Explorateurs et Scientifiques. The French and Natural History in Singapore; First Printers; Low, M.E.Y., Pockington, K., Josuh, W.F.A., Eds.; Lee Kong Chian Natural History Museum: Singapore, 2019; pp. 234-253.

178. Aikawa, H. On larval forms of some Brachyura, Paper II: A note on indeterminate zoeas. Rec. Oceanogr. Work. Jpn. 1933, 5, 124-154.

179. Manning, R.B. Three genera removed from the synonymy of Pinnotheres Bosc, 1802 (Brachyura: Pinnotheridae). Proc. Biol. Soc. Wash. 1993, 106, 523-531.

180. Tesch, J.J. Siboga Expeditie: The Decapoda Brachyura of the Siboga Expedition I-Hymenosomidae. Retroplumidae, Ocypodidae, Grapsidae and Gecarcinidae; E.J. Brill: Leiden, The Netherlands, 1918; pp. 1-148.

181. Jiang, W.; Liu, R. New species and new records of pinnotherid crabs (Crustacea: Decapoda: Brachyura) from the Yellow Sea. Zool. Anz. 2011, 250, 488-496. [CrossRef]

182. Sakai, T. The Crabs of Sagami Bay Collected by His Majesty the Emperor of Japan; Maruzen Co.: Tokyo, Japan, 1965; pp. 1-206.

183. Green, T.M. Pinnaxodes gigas, a new species of pinnotherid crab from the Gulf of California (Decapoda: Brachyura: Pinnotheridae). Proc. Biol. Soc. Wash. 1992, 105, 775-779.

184. Glassell, S.A. New or little known crabs from the Pacific coast of northern Mexico. Trans. San Diego Soc. Nat. Hist. 1935, 8, 91-106.

185. Campos, E.; De Campos, A.R.; Ramirez, J. Remarks on distribution and hosts for symbiotic crustaceans of the Mexican Pacific (Decapoda and Isopoda). Proc. Biol. Soc. Wash. 1992, 105, 753-759.

186. Sakai, K. On the occurrence of three species of crabs on Shikoku Island, Japan, and a new species, Pinnotheres taichungae nov. spec., from Taiwan (Decapoda, Brachyura). Crustaceana 2000, 73, 1155-1162. [CrossRef]

187. Yamada, M.; Ishibashi, R.; Toyoda, K.; Kawamura, K.; Komaru, A. Phylogeography of the brackish water clam Corbicula japonica around the Japanese archipelago inferred from mitochondrial COII gene sequences. Zool. Sci. 2014, 31, 168-179. [CrossRef] [PubMed]

188. Nobili, M.G. Diagnoses préliminaires de 34 espèces et variétés nouvelles, et de 2 genres nouveaux de décapodes de la Mer Rouge. Bull. Muséum D’histoire Nat. Paris Prem. Séries 1906, 6, 393-411.

189. Laurie, R.D. Reports on the marine biology of the Sudanese Red Sea. -XXI. On the Brachyura. J. Linn. Soc. Lond. Zool. 1915, 31, 407-475. [CrossRef]

Publisher's Note: MDPI stays neutral with regard to jurisdictional claims in published maps and institutional affiliations.

(C) 2020 by the authors. Licensee MDPI, Basel, Switzerland. This article is an open access article distributed under the terms and conditions of the Creative Commons Attribution (CC BY) license (http://creativecommons.org/licenses/by/4.0/). 